Article

\title{
High Temperature Oxidation Behavior of Selective Laser Melting Manufactured IN 625
}

\author{
Mihaela Raluca Condruz ${ }^{1, *}$, Gheorghe Matache ${ }^{1,2}{ }^{-}$, Alexandru Paraschiv ${ }^{1}$, Teodor Badea ${ }^{1}$ \\ and Viorel Badilita ${ }^{3}$ \\ 1 Romanian Research and Development Institute for Gas Turbines COMOTI, 220D Iuliu Maniu Av., \\ 061126 Bucharest, Romania; gheorghe.matache@comoti.ro (G.M.); alexandru.paraschiv@comoti.ro (A.P.); \\ teodor.badea@comoti.ro (T.B.) \\ 2 Technical Sciences Academy of Romania, 26 Dacia Av., 1, 010413 Bucharest, Romania \\ 3 National Research \& Development Institute for Non-Ferrous and Rare Metals-IMNR, Biruinttei 102 Av., \\ 077145 Pantelimon, Ilfov County, Romania; viobadilita@yahoo.com \\ * Correspondence: raluca.condruz@comoti.ro; Tel.: +40-768-625-916
}

Received: 15 April 2020; Accepted: 18 May 2020; Published: 20 May 2020

check for updates

\begin{abstract}
The high-temperature oxidation behavior of selective laser melting (SLM) manufactured IN 625 was studied over $96 \mathrm{~h}$ of exposure at $900{ }^{\circ} \mathrm{C}$ and $1050{ }^{\circ} \mathrm{C}$ in air. An extensive analysis was performed to characterize the oxide scale formed and its evolution during the $96 \mathrm{~h}$, including mass gain analysis, EDS, XRD, and morphological analysis of the oxide scale. The mass gain rate of the bare material increases rapidly during the first $8 \mathrm{~h}$ of temperature holding and diminishes at higher holding periods for both oxidation temperatures. High-temperature exposure for short periods $(24 \mathrm{~h})$ follows a parabolic law and promotes the precipitation of $\delta$ phase, Ni-rich intermetallics, and carbides. Within the first $24 \mathrm{~h}$ of exposure at $900{ }^{\circ} \mathrm{C}$, a $\mathrm{Cr}_{2} \mathrm{O}_{3}$ and a $(\mathrm{Ni}, \mathrm{Fe}) \mathrm{Cr}_{2} \mathrm{O}_{4}$ spinel scale were formed, while at a higher temperature, a more complex oxide was registered, consisting of $(\mathrm{Ni}, \mathrm{Fe}) \mathrm{Cr}_{2} \mathrm{O}_{4}$, $\mathrm{Cr}_{2} \mathrm{O}_{3}$, and rutile-type oxides. Prolonged exposure of IN 625 at $900{ }^{\circ} \mathrm{C}$ induces the preservation of the $\mathrm{Cr}_{2} \mathrm{O}_{3}$ scale and the dissolution of carbides. Other phases and intermetallics, such as $\gamma, \delta$ phases, and $\mathrm{MoNi}_{4}$ are still present. The exposure for $96 \mathrm{~h}$ at $1050{ }^{\circ} \mathrm{C}$ led to the dissolution of all intermetallics, while the same complex oxide scale was formed.
\end{abstract}

Keywords: IN 625; SLM; oxidation; additive manufacturing

\section{Introduction}

Nickel-based superalloys are metallic materials capable of withstanding high loading burdens during operation at high temperatures and in corrosive environments. Over the years, many chemical compositions were evaluated in order to obtain specific combinations that can ensure as many required properties as possible. Therefore, based on experimental studies, it was ascertained that superalloys designed for maximum strength do not provide the maximum oxidation resistance, and vice versa $[1,2]$. IN 625 is a Ni-Cr superalloy developed in the 1950s as a substitute for stainless steel used in power plant components [3]. Even though it was developed 70 years ago, it is still known for its outstanding properties in oxidative and corrosive environments, with the high $\mathrm{Cr}$ content providing corrosion resistance while $\mathrm{Mo}$ and $\mathrm{Nb}$ ensure the strengthening of the face-centered cubic (FCC) structure $\gamma$ phase [4,5]. In oxidative environments, the base material is protected by chromium oxide $\left(\mathrm{Cr}_{2} \mathrm{O}_{3}\right)$ or aluminum oxide $\left(\mathrm{Al}_{2} \mathrm{O}_{3}\right)$ scale formation [6-12], with $\mathrm{Al}$ being the most effective alloying element used to enhance oxidation resistance, and $\mathrm{Cr}$ being an element that reduces the oxidation rate of superalloys without W [6]. 
Under different environmental conditions, several oxide types can develop on the surface of high $\mathrm{Cr}$ content Ni-based superalloys. In oxidative environments, even at temperatures below $800{ }^{\circ} \mathrm{C}$, for $\mathrm{Cr}$ contents over $10 \mathrm{wt} \%$, stable oxides nuclei of $\mathrm{Ni}$ and $\mathrm{Cr}$ can grow $[7,13]$. Prior to reaching a steady-state oxide scale development, a preliminary transient oxidation period was reported by some authors. During this transient period, $\mathrm{NiO}$ nuclei grow faster than the $\mathrm{Cr}_{2} \mathrm{O}_{3}$ nuclei. As a result, a continuous layer of $\mathrm{NiO}$ forms and incorporates the $\mathrm{Cr}_{2} \mathrm{O}_{3}$ nuclei. Further, $\mathrm{Cr}_{2} \mathrm{O}_{3}$ reacts with $\mathrm{NiO}$, resulting in a fragmented or a compact layer of $\mathrm{NiCr}_{2} \mathrm{O}_{4}$ spinel. The transient period is completed as the initial $\mathrm{Cr}_{2} \mathrm{O}_{3}$ nuclei grow at the scale-base material interface and form a continuous layer $[7,8,13,14]$. Such a transient oxidation period was reported by some authors even at higher temperatures [15-20].

Many studies were conducted regarding the oxidation behavior of Ni-Cr superalloys, and from a kinetic point of view, three oxidation behaviors were reported: a parabolic, a logarithmic, and a linear oxidation behavior [21]. Moreover, the scale's stability and temperature dependence can be explained by Ellingham diagrams. Staszewska et al. [22] studied the oxidation mechanism and kinetics for IN 617 and IN 625. For these materials, they obtained compact oxide scales composed of an exterior $\mathrm{Cr}_{2} \mathrm{O}_{3}$ and internal $\mathrm{NiCr}_{2} \mathrm{O}_{4}$ spinel along with other oxides. The $\mathrm{NiCr}_{2} \mathrm{O}_{4}$ spinel was observed also by Vesel et al. [23] for IN 625 and a similar spinel $\left(\mathrm{NiAl}_{2} \mathrm{O}_{4}\right)$ was found by Zhang et al. [12] in the case of a Ni-Fe based superalloy. Molins et al. [24] studied the oxidation behavior of Ni superalloys at $650{ }^{\circ} \mathrm{C}$, and they noticed a complex oxide scale consisting in an outer $\mathrm{NiO}$ containing $\mathrm{Cr}$ and $\mathrm{Fe}$, followed by $\mathrm{Cr}_{2} \mathrm{O}_{3}$ and $\mathrm{Cr}(\mathrm{Nb}, \mathrm{Ti}) \mathrm{O}_{4}$ near the baseline alloy. Thermodynamically, $\mathrm{Cr}_{2} \mathrm{O}_{3}$ is the main stable oxide until $900{ }^{\circ} \mathrm{C}$, but different deleterious types $\left(\mathrm{CrO}_{2}(\mathrm{OH})_{2}, \mathrm{CrO}_{3}\right)$ can develop and promote $\mathrm{Cr}$ volatilization $[17,21,25]$.

Although so many studies were realized regarding conventionally-produced superalloys, nowadays a particular area has to be addressed-the performances of additive-manufactured (AMed) metals. Within the next few years, the integration of additive manufacturing technology in the industrial field is very likely, so many studies are conducted regarding raw materials used for AM [26] and AMed alloy characterization [27,28]. Conventional manufactured IN 625 is an alloy extensively used for parts that operate in oxidative and corrosive environments, such as components for industrial and aerospace gas turbines, as well as components for nuclear and marine power plants. By means of additive manufacturing technology, new complex shape components can be further developed using the same alloy, following design concepts that cannot be put into practice by conventional technologies. Considering these aspects, the present study is focused on analyzing the oxidation behavior of IN 625, additively manufactured using selective laser melting.

\section{Materials and Methods}

Specimens for isothermal oxidation were manufactured using a selective laser melting Lasertec 30 SLM machine and IN 625 metal powder within the 15-45 $\mu \mathrm{m}$ particle range (UK81572 lot from LPW Technology Ltd., Runcorn, United Kingdom). The chemical composition of the metal powder is presented in Table 1.

Table 1. Chemical composition of the IN 625 metal powder provided by LPW Technology Ltd.

\begin{tabular}{cccccccccccc}
\hline Chemical Elem. & Al & C & Co & Cr & Fe & Mn & Mo & Nb & Si & Ti & Ni \\
\hline Specification [wt\%] & $<0.4$ & $<0.1$ & $<1.0$ & $20-23$ & $3-5$ & $<0.5$ & $8-10$ & $3.15-4.15$ & $<0.5$ & $<0.4$ & Bal. \\
UK81572 [wt\%] & 0.06 & 0.02 & 0.1 & 20.7 & 4.1 & 0.01 & 8.9 & 3.77 & 0.01 & 0.07 & 62.26 \\
\hline
\end{tabular}

The following process parameters were used: $80^{\circ} \mathrm{C}$ temperature for the building plate, $50 \mu \mathrm{m}$ layer thickness, $0.11 \mathrm{~mm}$ hatch distance, $250 \mathrm{~W}$ laser power, $750 \mathrm{~mm} / \mathrm{s}$ laser speed, and $90^{\circ} \mathrm{scanning}$ strategy rotated with $90^{\circ}$ between two successive layers. For isothermal oxidation, $11 \mathrm{~mm}$ in diameter and $80 \mathrm{~mm}$ long cylindrical rods were produced. All cylindrical rods were mechanically detached from the building plate and the support material was mechanically removed. They were machined and ground to a diameter of $9 \mathrm{~mm}$. Also, $15 \mathrm{~mm}$ height cylindrical specimens were cut, and 18 specimens were obtained. Two specimens were kept as references and the others were used for 
the oxidation process. All specimens, as well as the $\mathrm{Al}_{2} \mathrm{O}_{3}$ crucibles, were degreased with ethanol and were weighted with and without the crucible using an analytic balance Pioneer PX224 (Ohaus, Shanghai, China). High-temperature oxidation influence was assessed by performing isothermal oxidation heat treatment at two different temperatures, $900{ }^{\circ} \mathrm{C}$ and $1050{ }^{\circ} \mathrm{C}$, using a Nabertherm LH 30/14 furnace (Nabertherm GmbH, Lilienthal/Bremen, Germany) $\left(\mathrm{P}=10 \mathrm{~kW}\right.$, Tmax $=1400{ }^{\circ} \mathrm{C}$ ). Oxidation temperatures were selected corresponding to the working temperature of gas turbines parts (over $1000^{\circ} \mathrm{C}$ ) and the limitations of conventionally-manufactured IN 625 superalloy $\left(900{ }^{\circ} \mathrm{C}\right.$ for short periods of time). The oxidation process was realized over 12 cycles of $8 \mathrm{~h}$ each until $96 \mathrm{~h}$ of total exposure time was reached. Each oxidation cycle consisted of heating the specimens placed in crucibles from room temperature to $900{ }^{\circ} \mathrm{C}$, and respectively $1050^{\circ} \mathrm{C}$, with a heating rate of $10^{\circ} \mathrm{C} / \mathrm{min}$. and $8 \mathrm{~h}$ holding at temperature, followed by slow cooling with the furnace.

The mass gains of the specimens were assessed after completing each oxidation cycle by weighing the specimens along with the crucible. After every $24 \mathrm{~h}$ high-temperature exposure time, two crucibles were removed from the furnace for material microstructural characterization and oxide scale analysis. The oxide scale analysis consisted of microstructural and morphological analysis by scanning electron microscopy using a FEI F50 Inspect SEM (FEI Company, Brno, Czech Republic), equipped with an energy-dispersive X-ray spectrometer (EDS) EDAX APEX 2i with SDD Apollo X detector (EDAX Inc., Ametek MAD Mahwah, NJ, USA). The morphology of the oxide scale was investigated on secondary electron images (ETD detector-Everhart Thornley Detector, FEI Company), while to highlight the differences in the chemical composition of the phases, backscattered electron images (vCD detector-low voltage high contrast detector, FEI Company) were used.

Microcompositional analysis was performed by SEM-EDS on the specimen's surface and in 4 different microareas in the specimen's cross-section. The qualitative analysis was performed using an acceleration voltage of $30 \mathrm{kV}$, a take-off angle of $35.6^{\circ}$, and an acquisition time of $60 \mathrm{~s}$. The semi-quantitative standardless analysis of the bulk oxide scale was made using indirect method ZAF correction, as implemented in the commercial EDAX Genesis software V6.29 (EDAX Inc. Ametek MAD Magwah, NJ, USA).

The natures of phases present in the oxide scale were investigated using X-ray diffraction (XRD) with a Bruker D8 Advance diffractometer (Bruker AXS GmbH, Karlsruhe, Germany) in Bragg-Brentano geometry, assisted by the Diffrac.Eva Bruker software (2019, version 5.1.0.5) and ICDD database (Newton Square, Pennsylvania), Powder Diffraction File, PDF4 +2020 . The diffractograms were acquired under the following conditions: X-ray source $\mathrm{Cu} \mathrm{K} \alpha(\lambda=1.54060 \AA) ; 2 \theta$ angular range of $14-84^{\circ} ; 2 \theta$ step size of $0.03^{\circ}$; time/step of $5 \mathrm{~s}$ and graphite monochromator in the diffracted beam. Moreover, a dimensional evolution of the oxide scale's thickness was realized in the cross-section on resin-mounted specimens by processing SEM images using the Scandium software (Olympus Soft Imaging Solutions $\mathrm{GmbH}$, Münster, Germany). An average value of the oxide's thickness was determined based on 13 measurements made on 3 different SEM images of each oxidized specimens.

\section{Results}

\subsection{Mass Gain Analysis}

The mass gain analysis of the high-temperature-exposed specimens was assessed as the difference between the weight of the specimen after exposure and the initial weight, relative to the initial outer surface of the specimen. The weight of specimens placed in crucibles was measured with an accuracy of $0.1 \mathrm{mg}$. Figure 1 presents the isothermal oxidation kinetic curves of the SLM-manufactured alloy for a total $96 \mathrm{~h}$ exposure time at $900^{\circ} \mathrm{C}$ and $1050^{\circ} \mathrm{C}$, respectively. However, significant differences were highlighted for the two exposure temperatures. The mass gain of the specimens oxidized at $1050{ }^{\circ} \mathrm{C}$ is a few orders of magnitude higher than that of the specimens oxidized for the same period of time at $900{ }^{\circ} \mathrm{C}$. 


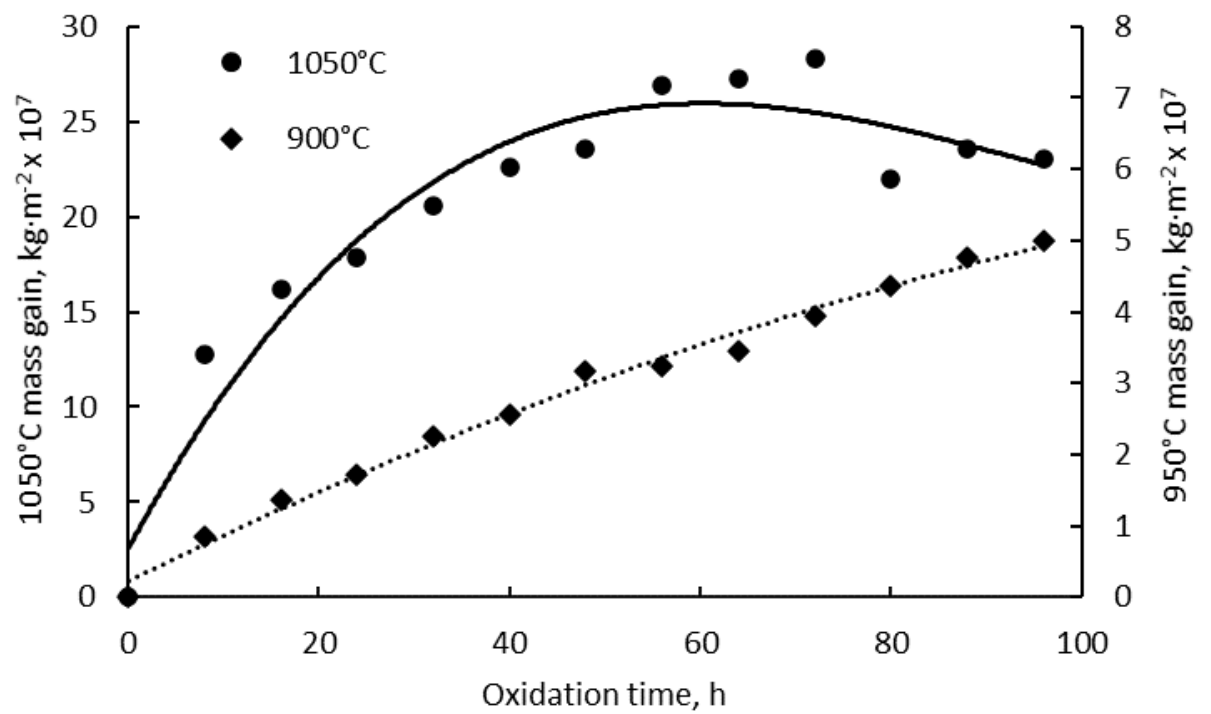

Figure 1. Kinetic curves of isothermal oxidation of IN 625 superalloy at $900{ }^{\circ} \mathrm{C}$ and $1050{ }^{\circ} \mathrm{C}$.

Although the mass gain of the oxidized specimens at $900{ }^{\circ} \mathrm{C}$ follows a parabolic law during the first $24 \mathrm{~h}$, it appears to be more linear as a function of exposure time for the rest of the oxidation time. The oxidation process at $1050{ }^{\circ} \mathrm{C}$ follows a nearly-parabolic law. An increase of the mass gain was registered until the 10th exposure cycle followed by the specimens' mass loss. Over the whole exposure period, the cumulative mass gain rate calculated for the specimens oxidized at the two temperatures as a function of time exhibits similar behavior, as shown in Figure 2. For both oxidation temperatures, the mass gain rate increases rapidly in the first $8 \mathrm{~h}$ of exposure time, after which the mass gain rate steadily diminishes.

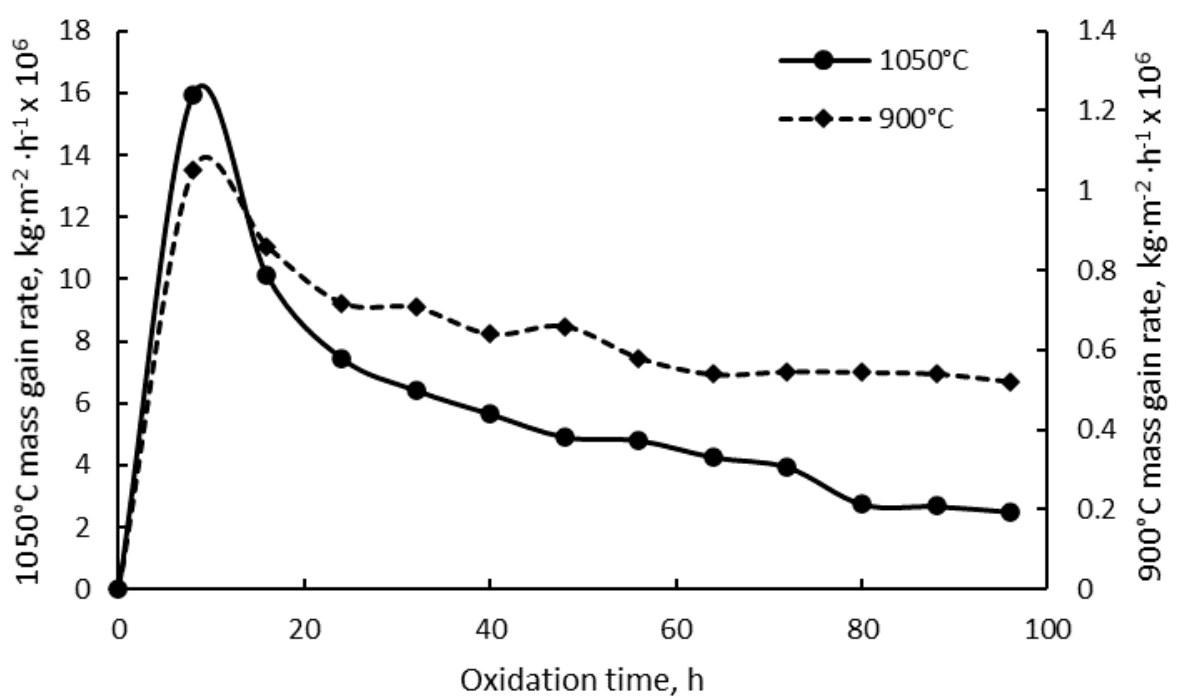

Figure 2. Cumulative mass gain rates of the specimens oxidized at $900{ }^{\circ} \mathrm{C}$ and $1050{ }^{\circ} \mathrm{C}$.

\subsection{Oxide Scale Analysis}

The EDS analysis of specimens' top surfaces revealed that in both cases, after a total of $96 \mathrm{~h}$ of oxidation, the process led to the formation of mainly chromium oxide scales. Small traces of $\mathrm{Mo}, \mathrm{Nb}$, and Fe were observed in the case of the oxidized specimens at $900{ }^{\circ} \mathrm{C}$, and only small traces of $\mathrm{Nb}$ and Fe were observed in the case of oxidized specimens at $1050^{\circ} \mathrm{C}$. Figure 3 presents the EDS spectrum realized on the top surfaces of oxidized specimens. 


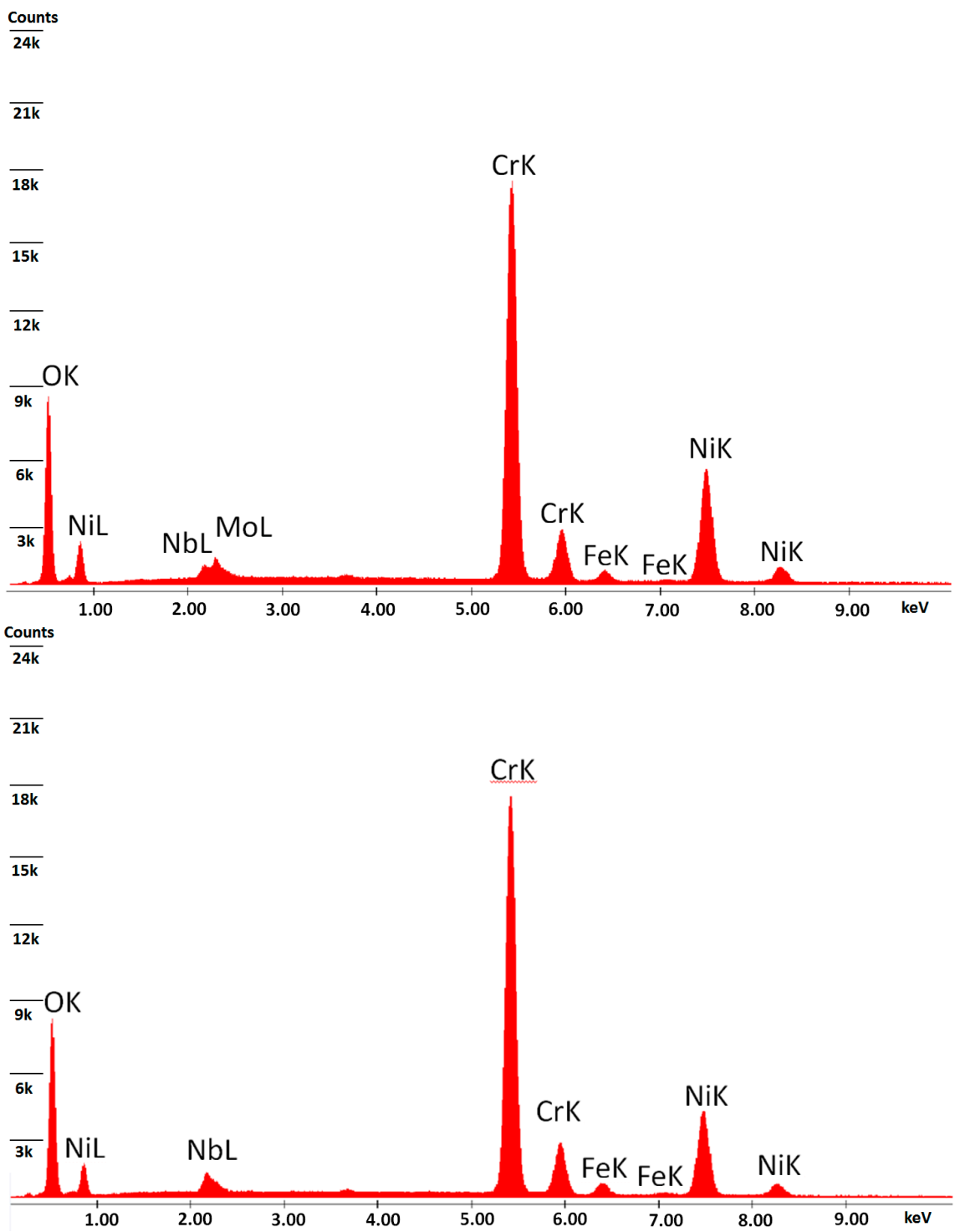

(a)

Figure 3. EDS spectra on the top surfaces of oxidized specimens at $900{ }^{\circ} \mathrm{C}(\mathbf{a})$ and $1050{ }^{\circ} \mathrm{C}(\mathbf{b})$.

The EDS analysis performed in four microareas (three in the oxide scale and one in the base material under the interface with the oxide layer) in the specimen's cross-section was realized in order to determine which chemical elements react with oxygen during its diffusion in the baseline material and whether a reduction in the overall metal at the specimen's surface is registered. Tables 2 and 3 present the result of the EDS analysis on four different microareas, as shown in Figure 4 for the specimen oxidized at $1050^{\circ} \mathrm{C}$, after $96 \mathrm{~h}$ of exposure, in an area where the oxide scale was unspalled. 


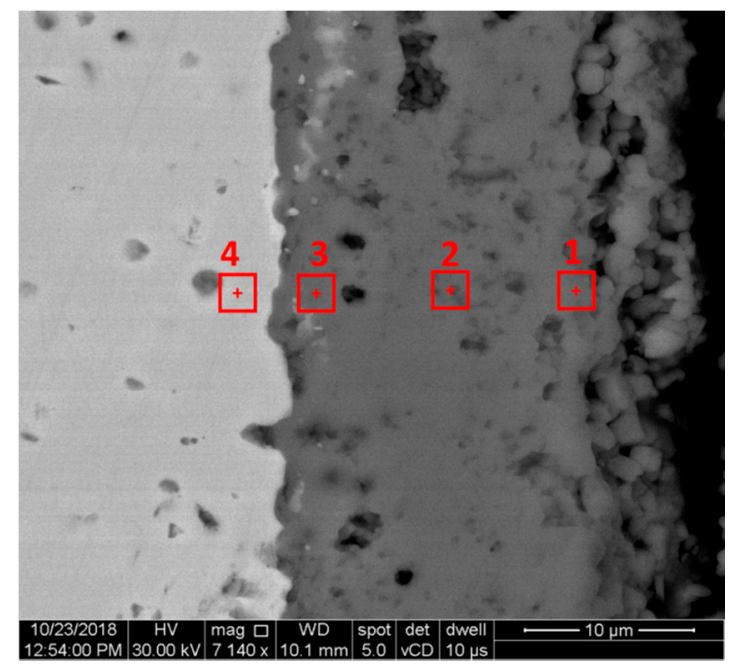

Figure 4. EDS analysis microareas in specimen's cross-section.

Table 2. Chemical composition evolution in the studied four microareas (oxidation at $900{ }^{\circ} \mathrm{C}$ ).

\begin{tabular}{|c|c|c|c|c|c|c|c|}
\hline Exposure Time [h] & EDS Microarea & $\begin{array}{c}\mathrm{O} \\
{[w t \%]}\end{array}$ & $\begin{array}{c}\mathrm{Nb} \\
{[\mathrm{wt} \%]}\end{array}$ & $\begin{array}{c}\text { Mo } \\
{[\mathrm{wt} \%]}\end{array}$ & $\begin{array}{c}\mathrm{Cr} \\
{[\mathrm{wt} \%]}\end{array}$ & $\begin{array}{c}\mathrm{Fe} \\
{[\mathrm{wt} \%]}\end{array}$ & $\begin{array}{c}\mathrm{Ni} \\
{[\mathrm{wt} \%]}\end{array}$ \\
\hline \multirow{4}{*}{24} & 1 & 24.85 & 4.24 & 5.99 & 38.75 & 2.30 & 23.87 \\
\hline & 2 & 28.74 & 4.64 & 6.87 & 33.13 & 2.22 & 24.40 \\
\hline & 3 & 28.51 & 5.68 & 8.38 & 27.11 & 2.16 & 28.17 \\
\hline & 4 & 5.26 & 5.70 & 12.35 & 16.84 & 4.51 & 55.34 \\
\hline \multirow{4}{*}{48} & 1 & 27.86 & 2.25 & 2.68 & 53.75 & 2.06 & 11.41 \\
\hline & 2 & 22.81 & 2.95 & 4.13 & 44.19 & 1.86 & 24.06 \\
\hline & 3 & 11.76 & 2.27 & 4.02 & 37.94 & 3.20 & 40.81 \\
\hline & 4 & 9.04 & 3.04 & 7.83 & 28.55 & 4.47 & 47.07 \\
\hline \multirow{4}{*}{72} & 1 & 16.87 & 1.73 & 1.97 & 69.53 & 1.34 & 8.57 \\
\hline & 2 & 17.57 & 1.87 & 1.95 & 68.33 & 1.30 & 8.98 \\
\hline & 3 & 19.54 & 1.81 & 2.24 & 63.12 & 1.63 & 11.67 \\
\hline & 4 & 6.30 & 10.23 & 12.84 & 19.85 & 3.13 & 47.65 \\
\hline \multirow{4}{*}{96} & 1 & 25.91 & 2.30 & 2.91 & 57.33 & 2.33 & 9.22 \\
\hline & 2 & 39.50 & 1.78 & 1.96 & 53.96 & 1.06 & 1.74 \\
\hline & 3 & 29.33 & 3.91 & 3.95 & 57.94 & 1.12 & 3.75 \\
\hline & 4 & 3.98 & 11.57 & 16.93 & 8.88 & 3.29 & 55.33 \\
\hline
\end{tabular}

EDS quantitative chemical composition of the specimen surface shows that after the first $24 \mathrm{~h}$ of the oxidation process at $900{ }^{\circ} \mathrm{C}$, the oxide scale contains, besides $\mathrm{Cr}$, different amounts of other oxide-forming alloying elements, such as $\mathrm{Ni}, \mathrm{Nb}, \mathrm{Mo}$, and $\mathrm{Fe}$. Thus, it can be concluded that the oxide scale consists of chromium oxide and other spinels or oxides containing these elements. After $48 \mathrm{~h}$ of exposure, the chromium content in the oxide scale increases to the detriment of the other elements. However, after $96 \mathrm{~h}$ of exposure at $900{ }^{\circ} \mathrm{C}$, apart from the high chromium content, all the other elements prone to forming intermetallics and/or other types of oxides, besides the predominant chromium oxide, are still present.

The chemical compositions presented in Table 3 show a different composition of the oxide scale for the specimens oxidized over the same duration at $1050{ }^{\circ} \mathrm{C}$. The specimens' surface is practically free of significant amounts $\mathrm{Mo}$ and Fe from the early stages, with small amounts of $\mathrm{Nb}$ and $\mathrm{Ni}$ being present apart of $\mathrm{Cr}$, as compared with the specimens oxidized at $900{ }^{\circ} \mathrm{C}$. The oxidation process at $1050^{\circ} \mathrm{C}$ ensures the formation of mainly chromium oxide starting from the incipient high-temperature maintenance cycles. 
Table 3. Chemical composition evolution in the studied four microareas (oxidation at $1050{ }^{\circ} \mathrm{C}$ ).

\begin{tabular}{cccccccc}
\hline Exposure Time [h] & EDS Microarea & $\begin{array}{c}\mathbf{O} \\
{[\mathbf{w t} \%]}\end{array}$ & $\begin{array}{c}\mathbf{N b} \\
{[\mathbf{w t} \%]}\end{array}$ & $\begin{array}{c}\mathbf{M o} \\
{[\mathbf{w t} \%]}\end{array}$ & $\begin{array}{c}\mathbf{C r} \\
{[\mathbf{w t} \%]}\end{array}$ & $\begin{array}{c}\mathbf{F e} \\
{[\mathbf{w t} \%]}\end{array}$ & $\begin{array}{c}\mathbf{N i} \\
{[\mathbf{w t} \%]}\end{array}$ \\
\hline \multirow{2}{*}{24} & 1 & 30.31 & 2.72 & - & 65.77 & - & 1.19 \\
& 2 & 25.56 & 1.88 & - & 71.07 & - & 1.49 \\
& 3 & 21.19 & 4.85 & - & 67.54 & - & 6.42 \\
48 & 4 & 3.59 & 6.27 & 14.33 & 13.91 & 5.05 & 56.85 \\
\hline \multirow{3}{*}{40} & 1 & 30.98 & 3.24 & - & 64.15 & - & 1.63 \\
& 2 & 24.79 & 2.1 & - & 71.51 & - & 1.6 \\
& 3 & 22.38 & 4.49 & - & 62.85 & - & 10.28 \\
& 4 & 1.65 & 6.83 & 13.84 & 10.5 & 4.88 & 62.31 \\
\hline \multirow{3}{*}{96} & 1 & 29.07 & 1.92 & - & 67.02 & - & 1.99 \\
& 2 & 24.11 & 1.77 & - & 72.48 & - & 1.64 \\
& 3 & 21.87 & 2.19 & - & 62.64 & - & 13.31 \\
& 4 & 2.61 & 6.74 & 14.07 & 9.44 & 5.19 & 61.95 \\
\hline & 1 & 25.6 & 2.43 & - & 70.35 & - & 1.62 \\
& 2 & 16.07 & 1.38 & - & 81.14 & - & 1.41 \\
& 3 & 18.78 & 5.74 & - & 68.87 & - & 6.61 \\
& 4 & 2.2 & 12.79 & 15.89 & 7.12 & 3.53 & 58.47 \\
\hline
\end{tabular}

A comparative analysis of the chemical composition of the oxide scales formed after $96 \mathrm{~h}$ of oxidation at the two temperatures was made by the ratio between the weight \% of $\mathrm{Cr}$ content and the sum of all alloying elements $(\Sigma \mathrm{AE})$ in the base material, i.e., $\mathrm{Cr}, \mathrm{Nb}, \mathrm{Mo}$, and Fe. Figure 5 presents the $w \mathrm{t} \% \mathrm{Cr} / \Sigma \mathrm{AE} w \mathrm{t} \%$ ratio calculated for the four EDS-analyzed microareas.

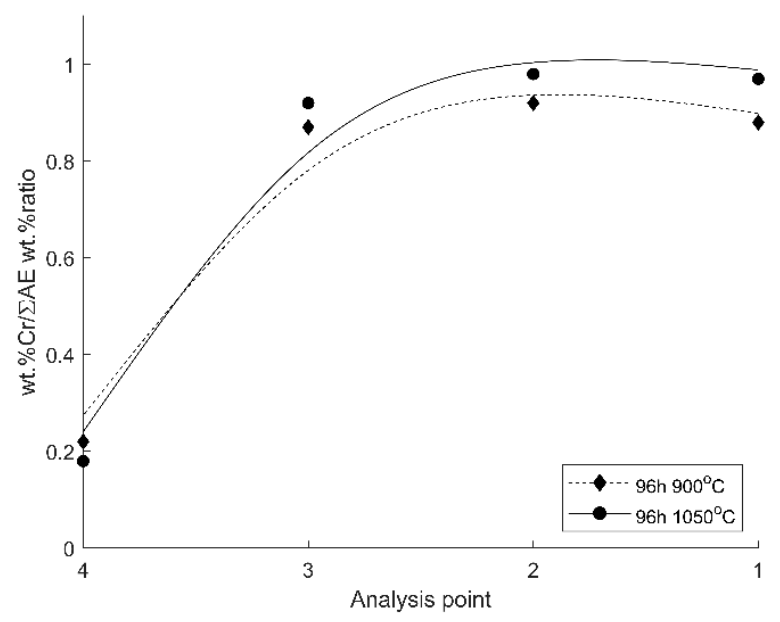

Figure 5. The $w \mathrm{t} \% \mathrm{Cr} / \Sigma \mathrm{AE} w \mathrm{t} \%$ ratio in the four analyzed microareas.

In the middle of the scale section (microarea 2) and the outer surface of the oxide scale (microarea 1), the specimens oxidized at $1050{ }^{\circ} \mathrm{C}$ exhibit a higher $\mathrm{Cr} / \Sigma \mathrm{AE}$ ratio than those oxidized at $900{ }^{\circ} \mathrm{C}$. For the specimens oxidized at $1050^{\circ} \mathrm{C}$, the $\mathrm{Cr}$ content in the total alloying elements represents $0.97-0.98$ ( $\mathrm{Cr} / \Sigma \mathrm{AE}$ close to unity), as compared with the lower $\mathrm{Cr} / \Sigma \mathrm{AE}$ ratio of $0.88-0.92$ for the specimens oxidized at $900{ }^{\circ} \mathrm{C}$.

In order to identify the repartition of the alloying elements in different oxides types and other phases formed in the scale, the oxidized specimens at both temperatures were subject to XRD phase analysis. Figure 6 presents the representative $2 \theta$ range $\left(33-66^{\circ}\right)$ of the diffractograms acquired from the specimens oxidized for $24 \mathrm{~h}$ at $900{ }^{\circ} \mathrm{C}$ and $1050{ }^{\circ} \mathrm{C}$, respectively, while Figure 7 presents the similar range of the diffractograms acquired from the specimens oxidized for $96 \mathrm{~h}$ at the same temperatures. 

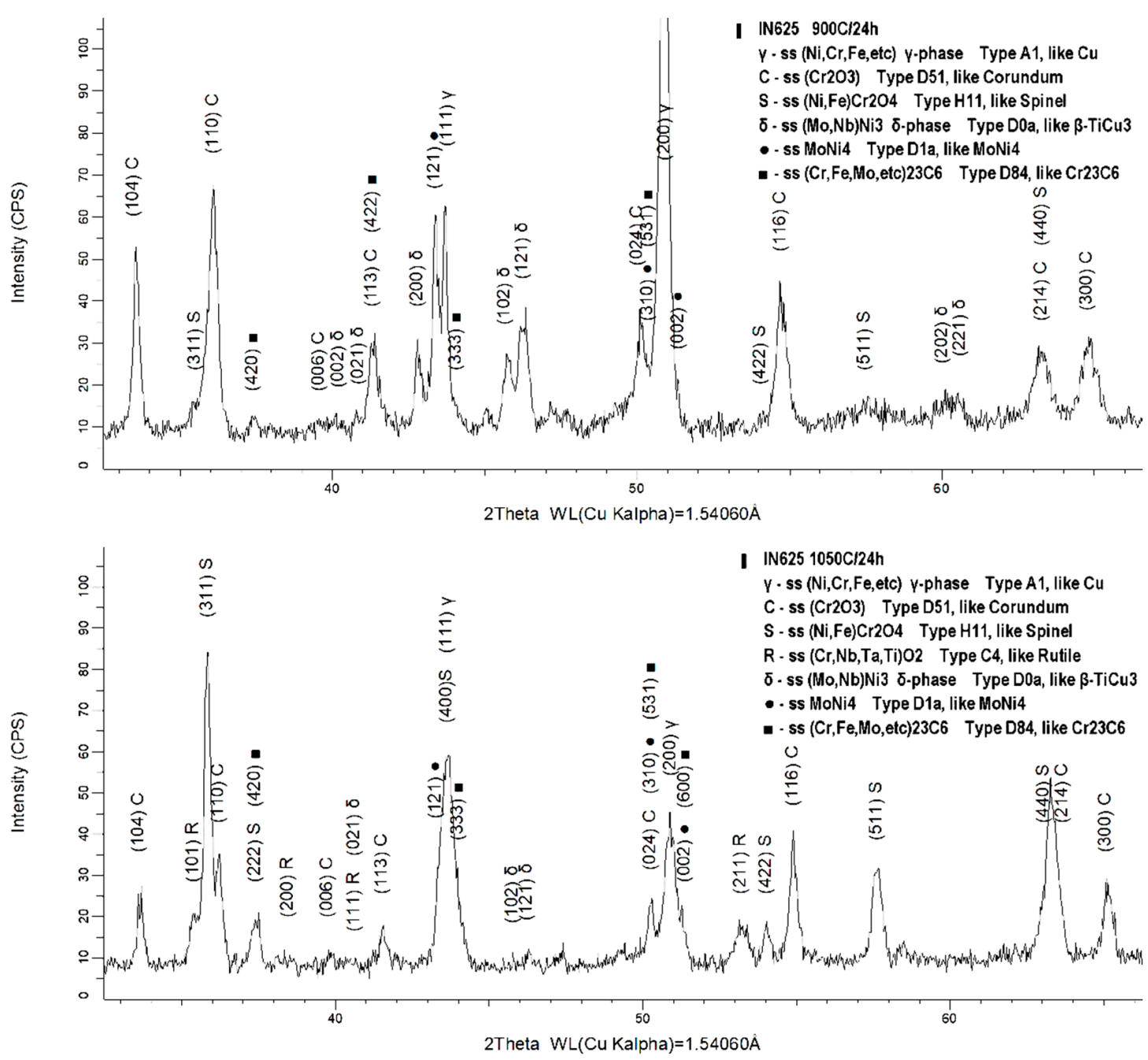

(a)

Figure 6. Diffraction patterns of the specimens oxidized for $24 \mathrm{~h}$ at $900{ }^{\circ} \mathrm{C}(\mathbf{a})$ and $1050{ }^{\circ} \mathrm{C}(\mathbf{b})$.

The phases identified by XRD are practically substitutional solid solutions (ss). Their exact formulas cannot be identified by XRD; however, the type of structure of each phase can be determined. The description of the phases identified by XRD in the analyzed oxidized samples is summarized in Table A1, Appendix A.

The isothermal oxidation at $900{ }^{\circ} \mathrm{C}$ and $1050{ }^{\circ} \mathrm{C}$ for small periods of time $(24 \mathrm{~h})$ promotes the precipitation of $\delta$ phase $\left((\mathrm{Mo}, \mathrm{Nb}) \mathrm{Ni}_{3}\right)$, an Ni-rich intermetallic $\left(\mathrm{MoNi}_{4}\right)$, and complex carbides $((\mathrm{Cr}, \mathrm{Fe}$, Mo, etc. $)_{23} \mathrm{C}_{6}$ ).

The oxide scale formed within $24 \mathrm{~h}$ at $900{ }^{\circ} \mathrm{C}$ consists mainly of $\mathrm{Cr}_{2} \mathrm{O}_{3}$ followed by the spinel $(\mathrm{Ni}$, $\mathrm{Fe}) \mathrm{Cr}_{2} \mathrm{O}_{4}$, while at $1050{ }^{\circ} \mathrm{C}$ it consists mainly in spinel $(\mathrm{Ni}, \mathrm{Fe}) \mathrm{Cr}_{2} \mathrm{O}_{4}$, followed by $\mathrm{Cr}_{2} \mathrm{O}_{3}$. Moreover, in case of oxidation at higher temperature $\left(1050{ }^{\circ} \mathrm{C}\right)$ another oxide characterized by a rutile-like structure $\left(\left(\left(\mathrm{Cr}^{+3}(\mathrm{Nb}, \mathrm{Ta})^{+5}\right)_{(1-\mathrm{x}) / 2},\left(\mathrm{Ti}^{+4}\right)_{\mathrm{x}}\right) \mathrm{O}^{-2}{ }_{2}\right)$ was identified.

After prolonged temperature exposure $(96 \mathrm{~h})$, in the case of specimens exposed at $900{ }^{\circ} \mathrm{C}$, the $\gamma$-FCC and $\delta$ phases were still present along with the $\mathrm{MoNi}_{4}$ intermetallic, but no more traces of carbides were identified, and the oxide scale consists in a form of $\mathrm{Cr}_{2} \mathrm{O}_{3}$. Compared with the lower temperature oxidation process, a different evolution was noticed in the case of the oxide scale formed at $1050{ }^{\circ} \mathrm{C}$. The prolonged exposure at a higher temperature led to the dissolution of the $\delta$ phase, $\mathrm{MoNi}_{4}$ intermetallic, and carbides, with only the $\gamma$ phase being identified. This can be attributed to the fact that the oxidation temperature is in the range of the solutioning heat treatment window of the IN 625 alloy, which has the very purpose of dissolving them. The oxide scale identified in this particular case consists in the $(\mathrm{Ni}, \mathrm{Fe}) \mathrm{Cr}_{2} \mathrm{O}_{4}$ spinel, $\mathrm{Cr}_{2} \mathrm{O}_{3}$ and rutile-like phase $\left(\left(\left(\mathrm{Cr}^{+3}(\mathrm{Nb}, \mathrm{Ta})^{+5}\right)_{(1-\mathrm{x}) / 2},\left(\mathrm{Ti}^{+4}\right)_{\mathrm{x}}\right) \mathrm{O}^{-2}{ }_{2}\right)$. 

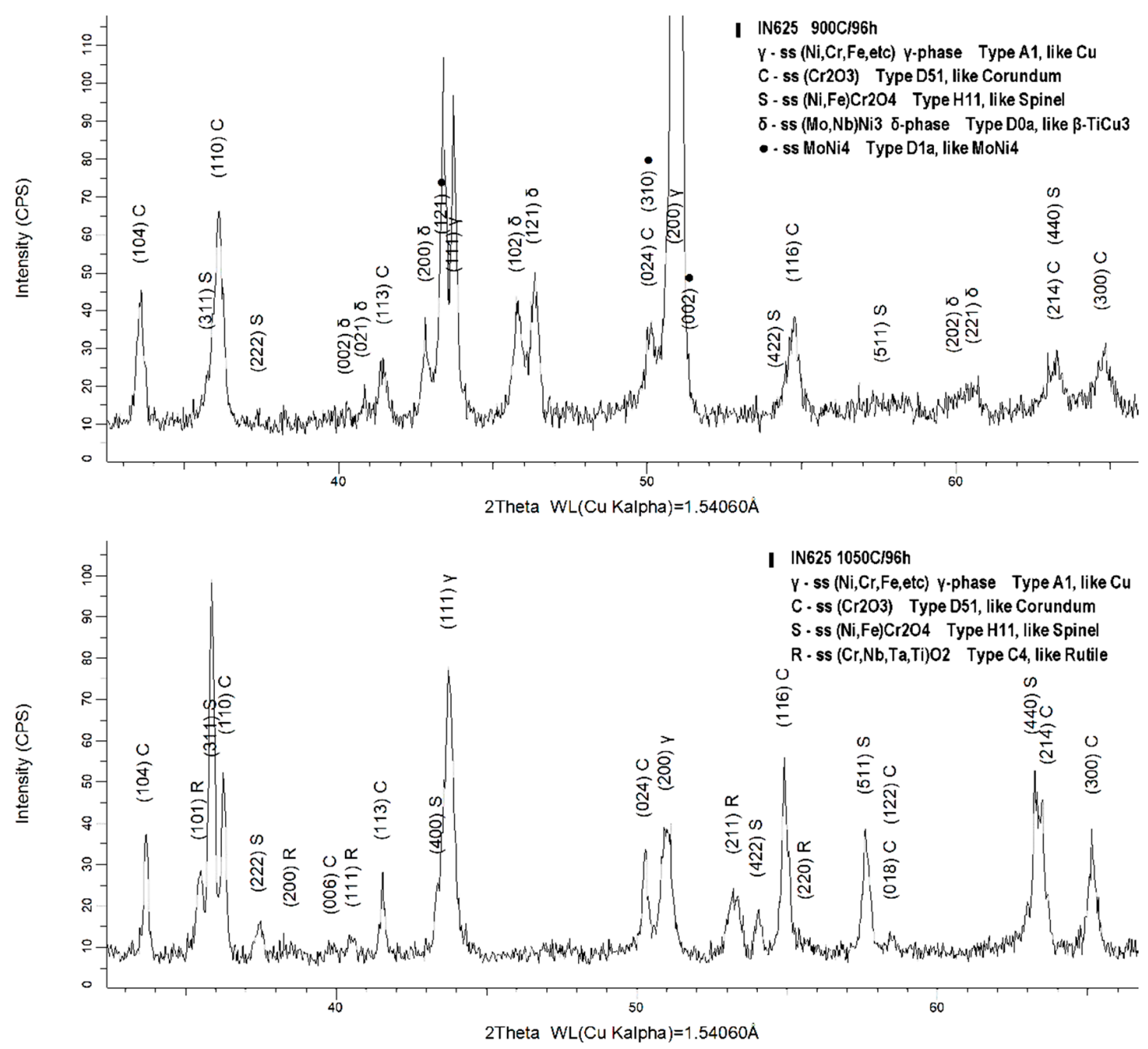

(a)

Figure 7. Diffraction patterns of the specimens oxidized for $96 \mathrm{~h}$ at $900{ }^{\circ} \mathrm{C}(\mathbf{a})$ and $1050{ }^{\circ} \mathrm{C}(\mathbf{b})$.

$\mathrm{XRD}$ is not able to distinguish between the spinel structures allowed by the elemental composition of this alloy (e.g., $\mathrm{NiCr}_{2} \mathrm{O}_{4}$-Nichromite, $\mathrm{FeCr}_{2} \mathrm{O}_{4}$-Chromite or $\mathrm{NiFe}_{2} \mathrm{O}_{4}$-Trevorite, etc.). One or more substitutional solid solutions (ss) with different compositions may be formed, possibly simultaneously in the oxide scale. The phase called $S$ refers to this situation. We have assumed for the $S$ phase the following approximate formula $\left(\mathrm{Ni}^{+2}, \mathrm{Fe}^{+2}\right)\left(\mathrm{Cr}^{+3}, \mathrm{Fe}^{+3}\right)_{2} \mathrm{O}_{4}$.

The same observations apply to natural complex carbides: $(\mathrm{Cr}, \mathrm{Fe}){ }_{23} \mathrm{C}_{6}$-Isovite, $(\mathrm{Fe}, \mathrm{Ni}){ }_{23} \mathrm{C}_{6}$-Haxonite or synthetic $\mathrm{Cr}_{23} \mathrm{C}_{6}, \mathrm{Mn}_{23} \mathrm{C}_{6}$ and so on, also admitting some $\mathrm{Mo}, \mathrm{Nb}$, Ta contents. We assumed for this phase the approximate formula $\left(\mathrm{Cr}, \mathrm{Fe}, \mathrm{Mo}\right.$, etc. ${ }_{23} \mathrm{C}_{6}$. A similar approach was justified by the proposal of the formulas of the corundum type oxide $(\mathrm{Cr}, \mathrm{Fe})_{2-2 x} \mathrm{Mo}_{x} \mathrm{O}_{3}$ and, respectively, rutile-type oxide $\left(\left(\mathrm{Cr}^{+3}(\mathrm{Nb}\right.\right.$, $\left.\left.\mathrm{Ta})^{+5}\right)_{(1-\mathrm{x}) / 2}\left(\mathrm{Ti}^{+4}\right)_{\mathrm{x}}\right) \mathrm{O}^{-2}{ }_{2}$ or $\left(\left(\mathrm{Cr}^{+3}(\mathrm{Nb}, \mathrm{Ta})^{+5}\right)_{(1-\mathrm{x})}\left(\mathrm{Ti}^{+4}\right)_{2 \mathrm{x}}\right) \mathrm{O}^{-2}{ }_{4}$.

The morphological evolution over time of the oxide scales formed on specimens' surface oxidized at $900{ }^{\circ} \mathrm{C}$ and $1050^{\circ} \mathrm{C}$, respectively, is presented in Figure 8. Comparing the SEM images, a different morphology of the developed oxide scales was noticed. The oxide scale formed at $900{ }^{\circ} \mathrm{C}$ presents an angular morphology compared with the rounder morphology observed in the case of the oxide scale formed at $1050{ }^{\circ} \mathrm{C}$.

Moreover, the oxide scale formed during oxidation at $1050{ }^{\circ} \mathrm{C}$ looks more porous than the oxide scale formed at lower temperatures, which is more compact. 


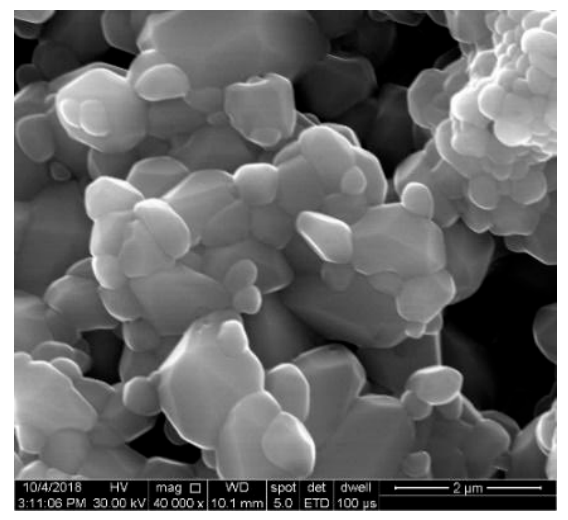

(a) $24 \mathrm{~h}-40.000 \mathrm{x}$

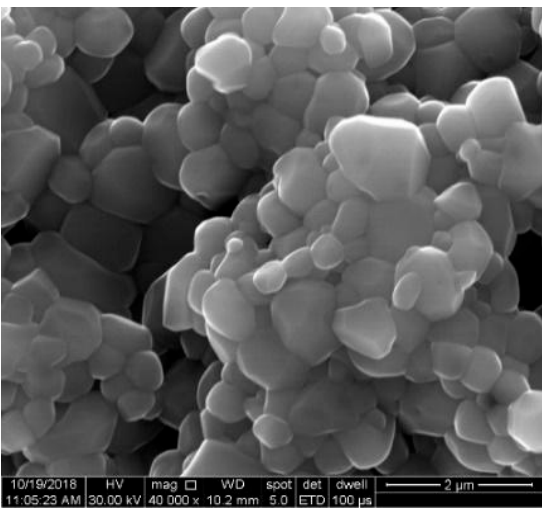

(c) $48 \mathrm{~h}-40.000 \mathrm{x}$

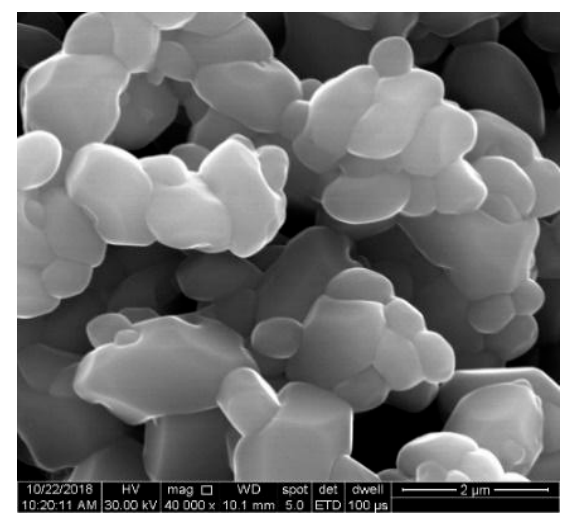

(e) $72 \mathrm{~h}-40.000 \mathrm{x}$

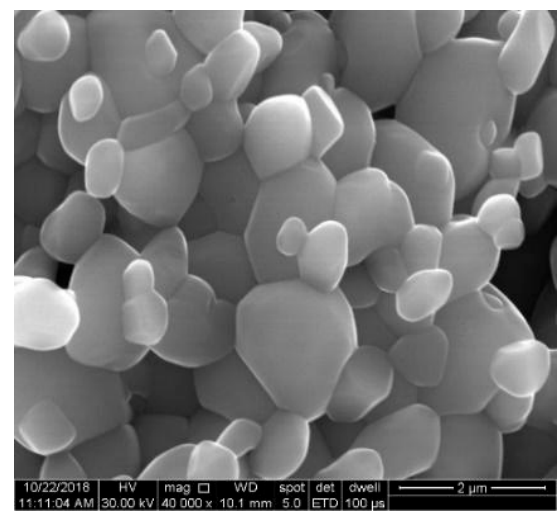

(g) $96 \mathrm{~h}-40.000 \mathrm{x}$

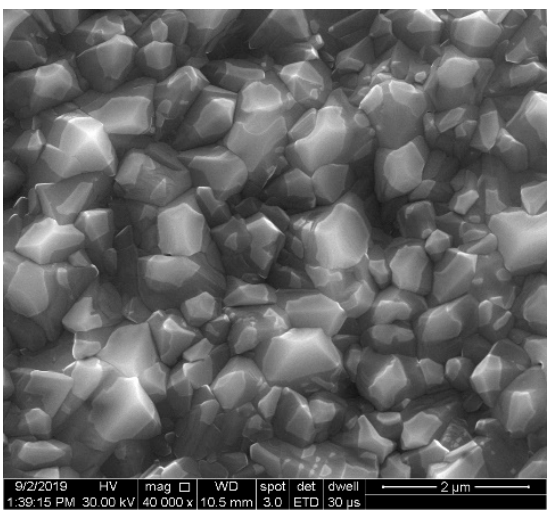

(b) $24 \mathrm{~h}-40.000 \mathrm{x}$

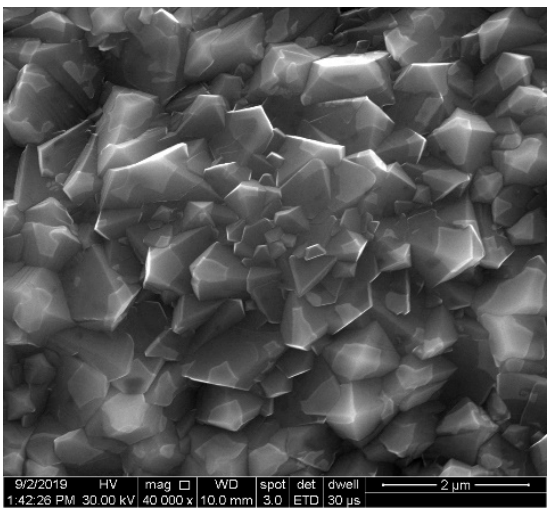

(d) $48 \mathrm{~h}-40.000 \mathrm{x}$

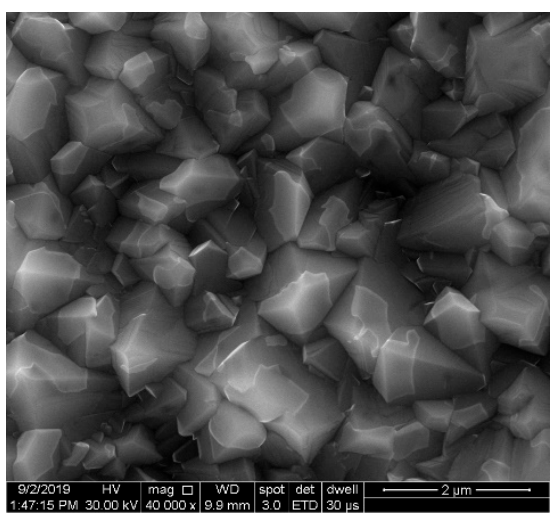

(f) $72 \mathrm{~h}-40.000 \mathrm{x}$

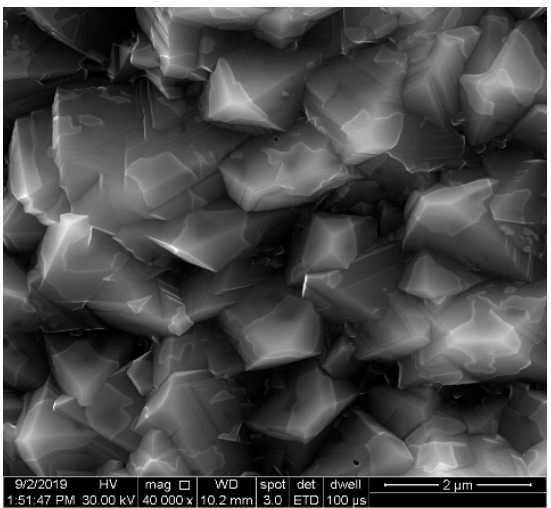

(h) $96 \mathrm{~h}-40.000 \mathrm{x}$

Figure 8. Microstructural evolution of the oxide scale over $96 \mathrm{~h}$ of isothermal oxidation at $1050{ }^{\circ} \mathrm{C}$ $(\mathbf{a}, \mathbf{c}, \mathbf{e}, \mathbf{g})$ and $900^{\circ} \mathrm{C}(\mathbf{b}, \mathbf{d}, \mathbf{f}, \mathbf{h})$. 
The evolution of oxide scale during the exposure time at the high temperature was assessed by thickness measurements on the specimen's cross-section, as shown for the illustration in Figure 9. Figure 10 presents the oxide scale's thickness evolution during the isothermal oxidation up to $96 \mathrm{~h}$ for both temperatures. The oxide scale thickness values are the average of 13 measurements done on 3 images for each exposure time. A parabolic evolution of the oxide scale thickness as a function of time was registered in both types of oxidation processes. A significant difference between the oxide scale's thicknesses for the two temperatures was registered. The thickness of the oxide scale formed at $1050{ }^{\circ} \mathrm{C}$ is almost double when compared with the oxide scale formed at $900{ }^{\circ} \mathrm{C}$. The oxide scale thickness increases fast during the first $24 \mathrm{~h}$ of exposure, then the increase is more moderate between 24-96 h at both temperatures. During the exposure between 24-96 h, the oxide scale thickness increases at $900{ }^{\circ} \mathrm{C}$ is lower than at $1050{ }^{\circ} \mathrm{C}$.

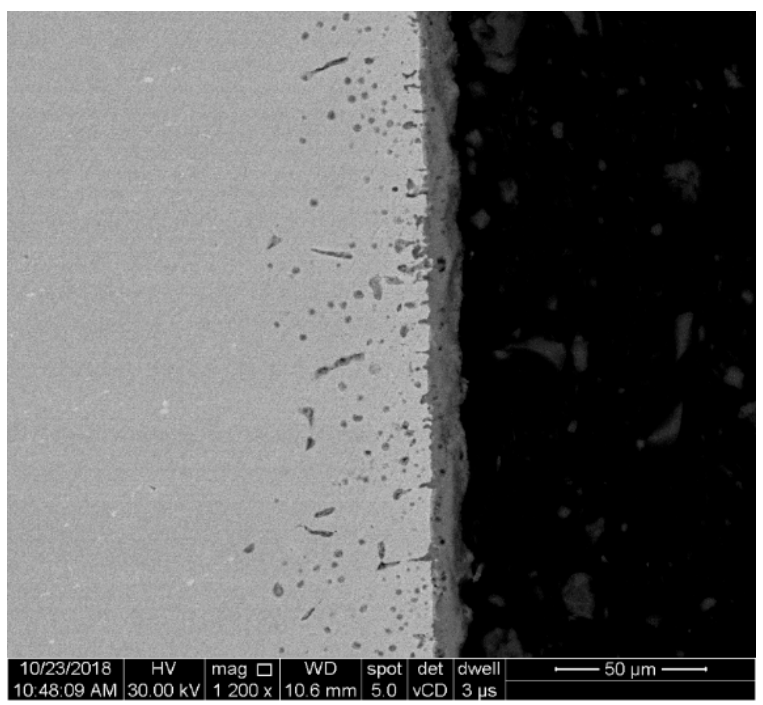

Figure 9. SEM image of a specimen cross-section used for oxide scale thickness measurement.

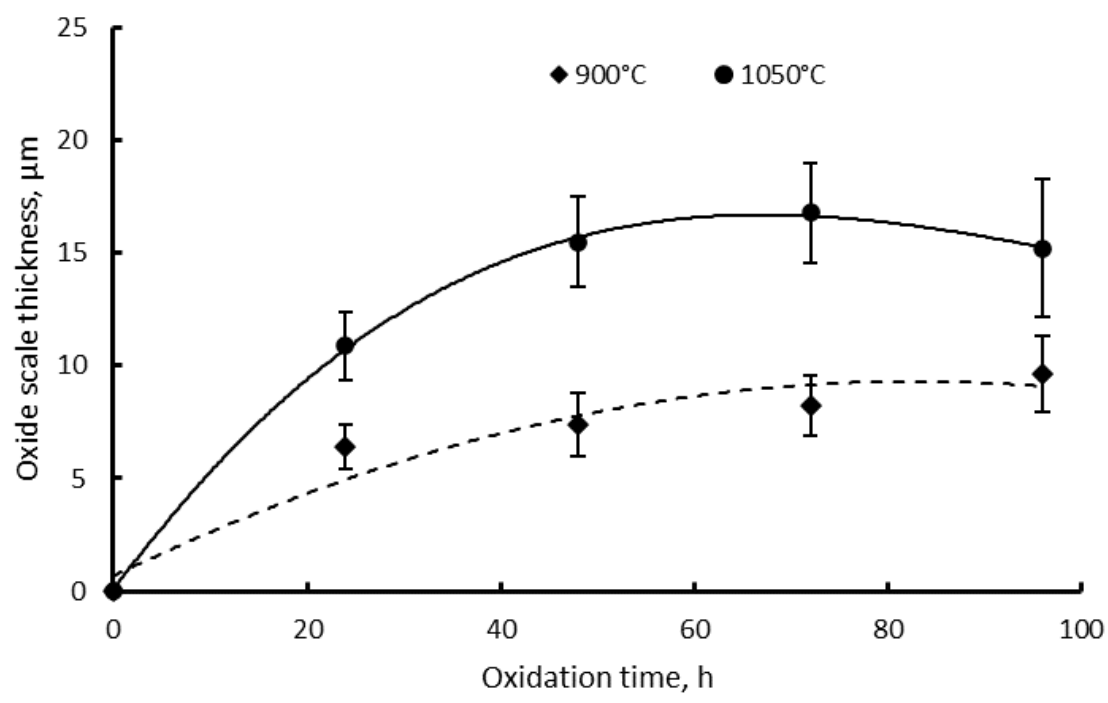

Figure 10. Oxide scale thickness as a function of time and standard deviations after isothermal oxidation of IN 625 at $900{ }^{\circ} \mathrm{C}$ and $1050{ }^{\circ} \mathrm{C}$.

The growth rate of the oxide scale thickness during the isothermal oxidation for $96 \mathrm{~h}$ is summarized in Figure 11. During the first $24 \mathrm{~h}$ of exposure, a high growth rate was registered for both oxidation temperatures, a lower rate being recorded in the case of oxidation at $900{ }^{\circ} \mathrm{C}$. During the first few oxidation cycles until $24 \mathrm{~h}$, the oxidation process is much faster at the higher temperature, whereupon the cumulative oxide scale growth rate gradually decreases. During the first cycles, the oxygen diffuses 
with a higher rate at the surface of the bare material, and as the oxide layer grows it becomes a barrier to oxygen diffusion.

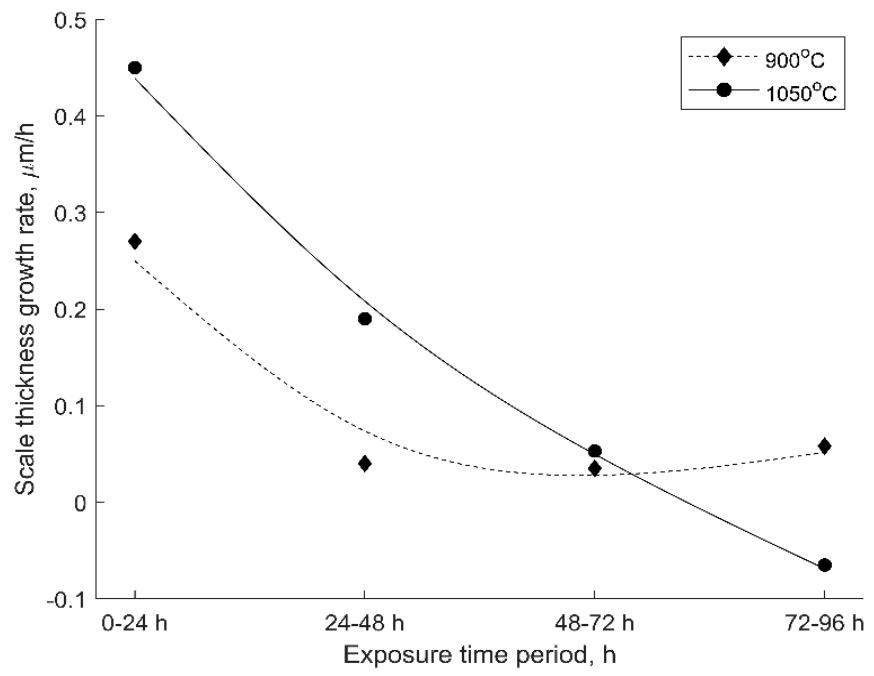

Figure 11. The oxide scale thickness growth rate as a function of the exposure time period.

In the case of oxidation at $900{ }^{\circ} \mathrm{C}$, the oxide scale growth rate stabilizes to a great extent between 48-64 h of exposure time. During this time period, the oxygen diffusion rate is slowed, but after the stabilization period, $\mathrm{Cr}_{2} \mathrm{O}_{3}$ continues to form, and an increase in the oxide scale growth rate was registered.

During the oxidation at $1050^{\circ} \mathrm{C}$, a significant steady decrease of the growth rate was registered after $24 \mathrm{~h}$ of exposure, reaching at $72 \mathrm{~h}$ a similar value as in case of the growth rate recorded at $900{ }^{\circ} \mathrm{C}$ oxidation.

As it was noticed in the case of mass gain and oxide thickness evolution analysis, oxidation for longer periods over $72 \mathrm{~h}$ at $1050{ }^{\circ} \mathrm{C}$ generates a decrease in the oxide's thickness, along with a reduction of the specimen's mass gain. This "negative" scale thickness growth rate recorded between $72-96 \mathrm{~h}$ of exposure time is caused by the oxide scale spallation. This was observed in different areas of the specimens oxidized at $1050^{\circ} \mathrm{C}$, starting from $72 \mathrm{~h}$ exposure, as shown in Figure 12 . The oxide scale spallation was not observed in the case of specimens oxidized at $900{ }^{\circ} \mathrm{C}$, the oxide scale formed in this case being denser and more even than the scale formed in the case of oxidized specimens at $1050{ }^{\circ} \mathrm{C}$.

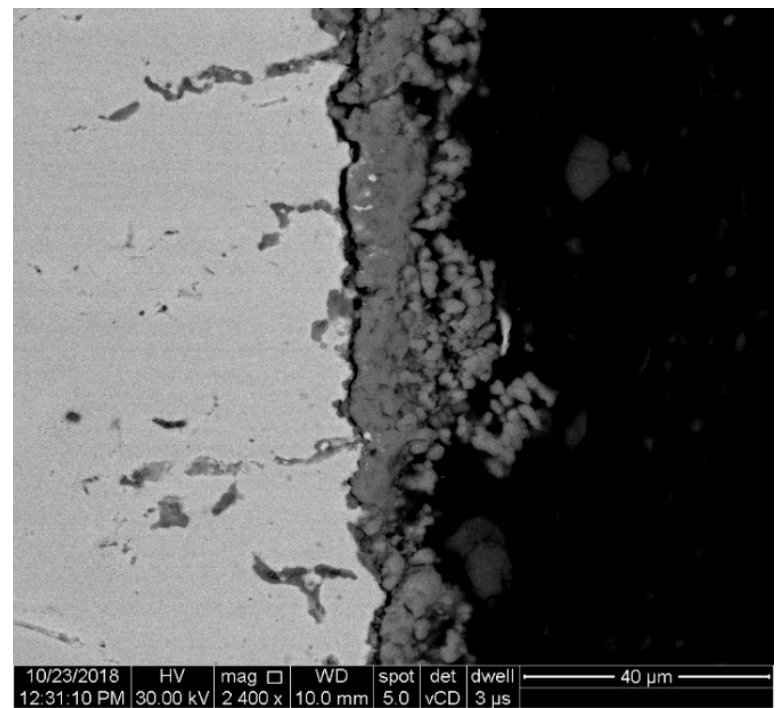

Figure 12. SEM image of the scale oxide's spallation at $1050{ }^{\circ} \mathrm{C}$ after $72 \mathrm{~h}$ exposure. 


\section{Discussion}

The high-temperature oxidation behavior of SLM-manufactured IN 625 was studied over $96 \mathrm{~h}$ of exposure in air at $900{ }^{\circ} \mathrm{C}$ and $1050{ }^{\circ} \mathrm{C}$, respectively. In both cases, the results of the mass gain analysis showed an increase of the specimens' weight during exposure. For both oxidation temperatures, the mass gain rate of the bare material increases rapidly in the first $8 \mathrm{~h}$ of exposure time (from 0 to $1.05 \times 10^{6} \mathrm{~kg} \cdot \mathrm{m}^{2} \cdot \mathrm{h}^{-1}$ for specimens oxidized at $900{ }^{\circ} \mathrm{C}$ and from 0 to $15.96 \times 10^{6} \mathrm{~kg} \cdot \mathrm{m}^{2} \cdot \mathrm{h}^{-1}$ for specimens oxidized at $1050^{\circ} \mathrm{C}$ ), after which the mass gain rate steadily diminished.

The oxidation kinetic of the material during the first $8 \mathrm{~h}$ of exposure is consistent with the fast kinetic reported by Berthod et al. [17] during the first $10 \mathrm{~h}$ of oxidation of a conventional manufactured $\mathrm{Ni}-\mathrm{Cr}(30 \mathrm{wt} \% \mathrm{Cr})$ alloy in the temperature range of $1000-1300{ }^{\circ} \mathrm{C}$.

The kinetic curves show a parabolic behavior of the mass gain as a function of time at the two oxidation temperatures in air. Yet, at the lower temperature of $900{ }^{\circ} \mathrm{C}$, after a parabolic behavior until the first $24 \mathrm{~h}$ of exposure, a steady mass gain was registered (with an almost linear dependence of the mass gain as a function of the exposure duration). This is consistent with other findings on Ni-based superalloys that show a sub-parabolic behavior at temperatures less than $900{ }^{\circ} \mathrm{C}$ and by following a parabolic law over $1000{ }^{\circ} \mathrm{C}$ [20,29-31]. No scale spallation was recorded for the $96 \mathrm{~h}$ oxidized samples at $900^{\circ} \mathrm{C}$. Similar behavior was reported by N'dah et al. [32] in the case of $50 \mathrm{~h}$ of oxidation of conventional manufactured IN 625 sheet at $900{ }^{\circ} \mathrm{C}$. Based on the experimental results, the calculated parabolic rate constants after $96 \mathrm{~h}$ of oxidation are $k_{p}=7.23 \times 10^{-11} \mathrm{~kg}^{2} \cdot \mathrm{m}^{-4} \cdot \mathrm{s}^{-1}$ at $900{ }^{\circ} \mathrm{C}$ and $k_{p}=1.67 \times 10^{-9} \mathrm{~kg}^{2} \cdot \mathrm{m}^{-4} \cdot \mathrm{s}^{-1}$ at $1050{ }^{\circ} \mathrm{C}$. Different $k_{p}$ values were reported for conventional manufactured IN625 or other Ni-Cr superalloys as summarized in Table 4, while similar values were determined by Juillet et al. for AMed IN 718 [33] and by Colas et al. [34], E.N'dah et al. [32], Buscail et al. [30] and Whitney et al. [35] for conventional manufactured (rolled/cast) IN 625. Slightly higher parabolic rate constants were reported by Kang et al. [29] in the case of 24 h oxidized 2 mm thick AMed IN 718. The difference can be explained by the post-processing treatments (solution heat treatment followed by aging or hot isostatic pressing (HIP) followed by aging) applied by Kang et al. [29] before the oxidizing treatment, as well as by the slightly lower $\mathrm{Cr}$ content and the higher content of $\mathrm{Al}$ and Ti. Moreover, at a lower $\mathrm{Cr}$ content (11.1 wt\%) compared with the $\mathrm{Cr}$ content of IN 625, a higher parabolic rate constant of $3.79 \times 10^{-8} \mathrm{~kg}^{2} \cdot \mathrm{m}^{-4} \cdot \mathrm{s}^{-1}$ was reported by Lund et al. [2].

Table 4. $k_{p}$ values registered for different oxidized Ni-based superalloys.

\begin{tabular}{|c|c|c|c|}
\hline$k_{p}$ Reported by Author & $\begin{array}{l}\text { Corresponding } k_{p} \text { in } \mathrm{kg}^{2} \cdot \mathrm{m}^{-4} \cdot \mathrm{s}^{-1} \\
\text { or Calculated from the Plot } \\
\text { Reported by the Author }\end{array}$ & $\begin{array}{c}\text { Material and Oxidation } \\
\text { Conditions }\end{array}$ & Reference \\
\hline $\begin{array}{l}7.23 \times 10^{-11} \mathrm{~kg}^{2} \cdot \mathrm{m}^{-4} \cdot \mathrm{s}^{-1} \\
1.67 \times 10^{-9} \mathrm{~kg}^{2} \cdot \mathrm{m}^{-4} \cdot \mathrm{s}^{-1}\end{array}$ & - & $\begin{array}{l}\text { AM IN } 625,900^{\circ} \mathrm{C} / 96 \mathrm{~h} \\
\text { AM IN } 625,1050^{\circ} \mathrm{C} / 96 \mathrm{~h}\end{array}$ & present work \\
\hline- & $2.8 \times 10^{-9} \mathrm{~kg}^{2} \cdot \mathrm{m}^{-4} \cdot \mathrm{s}^{-1}$ & $\begin{array}{c}\text { IN } 625 \text { (1 mm thick sheet) } \\
1100^{\circ} \mathrm{C} / 36 \mathrm{~h}\end{array}$ & J. Colas [34] \\
\hline $2 \times 10^{-3} \mathrm{mg}^{2} \cdot \mathrm{cm}^{-4} \cdot \mathrm{h}^{-1}$ & $6 \times 10^{-11} \mathrm{~kg}^{2} \cdot \mathrm{m}^{-4} \cdot \mathrm{s}^{-1}$ & $\begin{array}{l}\text { IN625 ( } 3 \mathrm{~mm} \text { thick sheet }) \\
900^{\circ} \mathrm{C} / 50 \mathrm{~h}\end{array}$ & \multirow{3}{*}{ E N'dah [32] } \\
\hline $3 \times 10^{-2} \mathrm{mg}^{2} \cdot \mathrm{cm}^{-4} \cdot \mathrm{h}^{-1}$ & $\begin{array}{l}7 \times 10^{-10} \mathrm{~kg}^{2} \cdot \mathrm{m}^{-4} \cdot \mathrm{s}^{-1} \\
3 \times 10^{-11} \mathrm{~kg}^{2} \cdot \mathrm{m}^{-4} \cdot \mathrm{s}^{-1}\end{array}$ & $\begin{array}{c}\text { IN625 ( } 3 \mathrm{~mm} \text { thick sheet }) \\
1000^{\circ} \mathrm{C} / 50 \mathrm{~h} \\
\text { IN625 }(3 \mathrm{~mm} \text { thick sheet }) \\
900^{\circ} \mathrm{C} / 100 \mathrm{~h}\end{array}$ & \\
\hline- & $1 \times 10^{-10} \mathrm{~kg}^{2} \cdot \mathrm{m}^{-4} \cdot \mathrm{s}^{-1}$ & $\begin{array}{l}\text { IN625 ( } 3 \mathrm{~mm} \text { thick sheet }) \\
1000{ }^{\circ} \mathrm{C} / 100 \mathrm{~h}\end{array}$ & \\
\hline- & $3.23 \times 10^{-9} \mathrm{~kg}^{2} \cdot \mathrm{m}^{-4} \cdot \mathrm{s}^{-1}$ & IN 625 , cast, $1100^{\circ} \mathrm{C} / 60 \mathrm{~h}$ & Whitney et.al., [35] \\
\hline $9.79 \times 10^{-6} \mathrm{mg}^{2} \cdot \mathrm{cm}^{-4} \cdot \mathrm{s}^{-1}$ & $9.79 \times 10^{-10} \mathrm{~kg}^{2} \cdot \mathrm{m}^{-4} \cdot \mathrm{s}^{-1}$ & $\begin{array}{l}\text { IN } 625 \text { (6 mm sheet) } \\
1000^{\circ} \mathrm{C} / 96 \mathrm{~h}\end{array}$ & \multirow{2}{*}{ Staszewska et. al., [22] } \\
\hline $9.90 \times 10^{-6} \mathrm{mg}^{2} \cdot \mathrm{cm}^{-4} \cdot \mathrm{s}^{-1}$ & $9.90 \times 10^{-10} \mathrm{~kg}^{2} \cdot \mathrm{m}^{-4} \cdot \mathrm{s}^{-1}$ & $\begin{array}{l}\text { IN } 625 \text { (6 mm sheet) } \\
1100^{\circ} \mathrm{C} / 96 \mathrm{~h}\end{array}$ & \\
\hline
\end{tabular}


Table 4. Cont

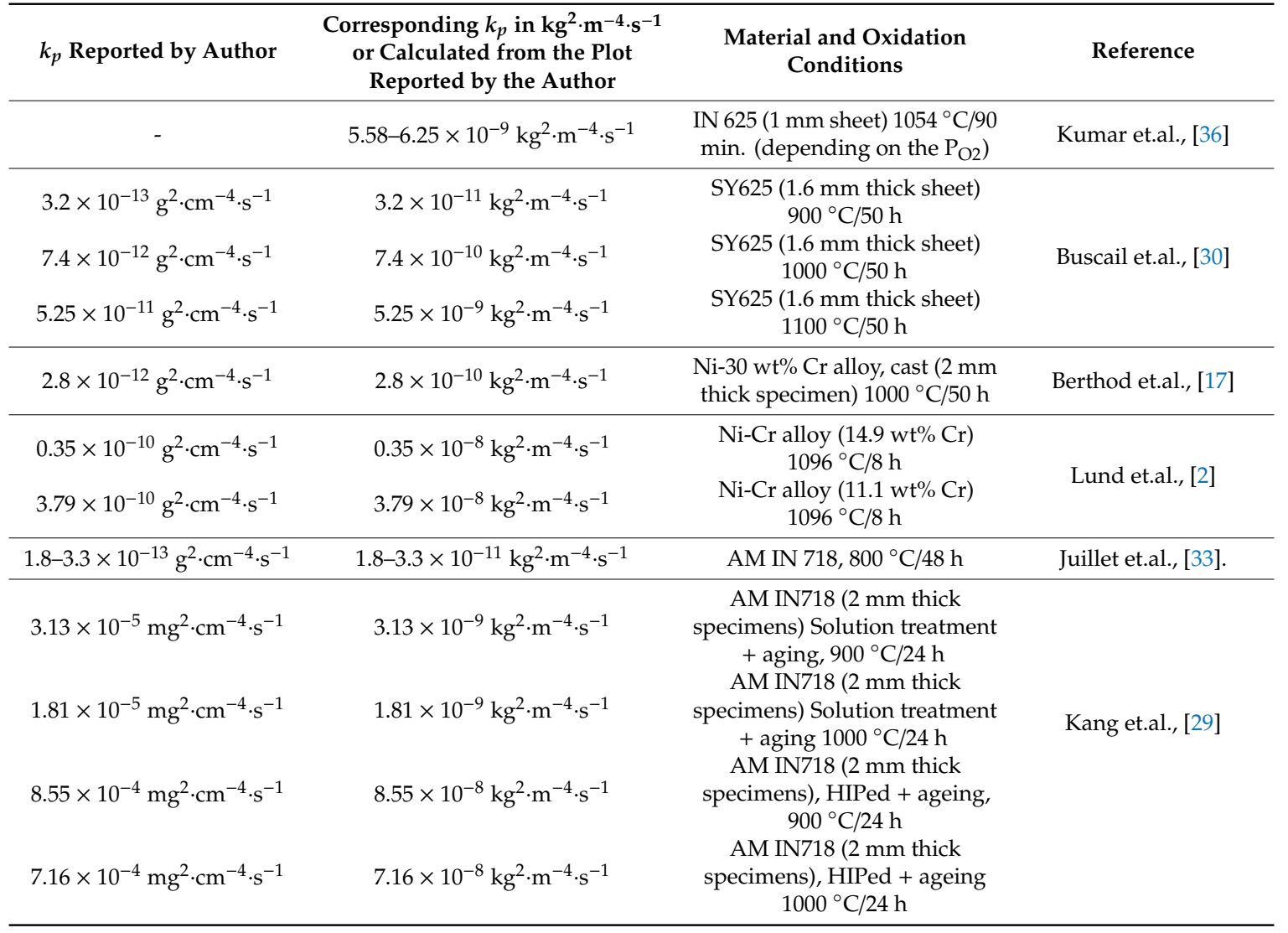

The oxidation activation energy $(\mathrm{Q})$ calculated as the slope of the Arrhenius plot of $k_{p}$ as a function of $1 / T$, where $T$ is the temperature in Kelvin, gives a value of $Q=269.9 \mathrm{~kJ} / \mathrm{mol}$ for a cumulative $96 \mathrm{~h}$ of oxidation time at $900{ }^{\circ} \mathrm{C}$ and $1050{ }^{\circ} \mathrm{C}$, respectively. Almost similar values of oxidation activation energy were reported by other authors for high $\mathrm{Cr}$ content conventional manufactured Ni-base alloys. Berthod et al. [17] obtained a slightly lower value, $242 \mathrm{~kJ} \cdot \mathrm{mol}^{-1}$, for oxidized Ni-30 $\mathrm{wt} \% \mathrm{Cr}$ superalloy at $1000{ }^{\circ} \mathrm{C}$, and Encinas-Opresa et al. [37] reported a value of $270 \mathrm{~kJ} \cdot \mathrm{mol}^{-1}$ for the RR1000 Ni-based superalloy $\left(15 \mathrm{wt} \% \mathrm{Cr}\right.$ ) between $700-800{ }^{\circ} \mathrm{C}$, while for the same alloy, Cruchley et al. [38] reported a higher value of $286 \mathrm{~kJ} \cdot \mathrm{mol}^{-1}$ between $600-900^{\circ} \mathrm{C}$.

For the specimens oxidized at $1050^{\circ} \mathrm{C}$, after the first exposure cycle, an almost constant mass gain until the 9th cycle (72 $\mathrm{h}$ exposure) was recorded, the oxide scale formation being characterized by a parabolic law. Voids and cavities were observed in the porous scale formed at $1050{ }^{\circ} \mathrm{C}$, consistent with the defects also found by $\mathrm{N}^{\prime}$ dah et al. [32] and Gorman et al. [39] in the oxide scale of conventional manufactured IN 625 .

After the 10th cycle, a different behavior was observed, with a weight decrease being recorded. This decrease in the specimen's weight was caused by oxide scale spallation. Oxide scale spallation and mass gain decrease were also noticed by other authors $[30,34,40]$. However, after the 10th oxidation cycle of AMed IN 625, the oxygen diffusion continues, and an increase of the specimen's weight was recorded during the following two oxidation cycles.

As it was observed in the case of mass gain analysis, a parabolic evolution was also registered for both oxide scale thicknesses after $96 \mathrm{~h}$ of exposure at $900{ }^{\circ} \mathrm{C}$ and $1050{ }^{\circ} \mathrm{C}$. The thickness measurements showed a fast growth of the oxide scale during the first $24 \mathrm{~h}$ of exposure for both oxidation temperatures, followed by a moderate growth after this cycle. In the case of the experiment realized at $900{ }^{\circ} \mathrm{C}$, a stabilization of the oxide scale growth rate was registered in the exposure range of 48-64 h. During this time period, the oxygen diffusion rate is slowed, consistent with the findings of Kitaguchi [14]. 
Due to a much faster oxidation rate, at $1050{ }^{\circ} \mathrm{C}$, the oxide scale had an almost double thickness compared with the scale obtained at $900{ }^{\circ} \mathrm{C}$. Moreover, the partial spallation of the oxide scale was observed by SEM after $72 \mathrm{~h}$ of exposure at $1050^{\circ} \mathrm{C}$, a phenomenon that was not observed for specimens oxidized at $900{ }^{\circ} \mathrm{C}$.

The oxide spallation could be caused by the oxidation kinetic, but it could be also influenced by the oxide's morphology. The SEM analysis performed on the specimen's top surface revealed a more compact oxide scale formed at $900^{\circ} \mathrm{C}$ than at $1050{ }^{\circ} \mathrm{C}$, where a more porous scale was formed. Dense compact oxide scales were obtained also by Juillet et al. for AMed IN 718 [33]. The two scales developed on AMed IN 625 exhibit different morphologies. An angular morphology was observed at the lower temperature, and a rounder morphology was observed at the higher temperature.

The EDS analysis performed in the four different microareas, in the oxide scale, and in the base material under the interface with the oxide layer, showed a higher Cr content at the oxide scale's level compared with the base material. The chemical composition of the base material under the interface with the oxide layer showed a partial depletion in $\mathrm{Cr}$ due to the formation of chromium oxide, which was observed for both high-temperature oxidation processes, followed by different other oxides or spinels. The surface of the base material depletion in $\mathrm{Cr}$ caused by the outward diffusion was observed also in case of AMed IN 718 [33]. Besides a depletion of $\mathrm{Cr}$ near the interface, a high content of $\mathrm{Nb}$ and Mo was registered, which is consistent with the findings of Chyrkin et al. [31,41] who reported that $\mathrm{Cr}$ influences the $\mathrm{Nb}$ and Mo activity causing an uphill diffusion to the $\mathrm{Cr}$-depleted zones towards the interface between the oxide and the alloy. This behavior was reported to be more pronounced in IN 625 thick specimens than in thin foils [41]. A high $\mathrm{Nb}$ content was highlighted in the oxide scale, caused by the standard free energy change of $\mathrm{Nb}$ oxidation reaction. Among the oxidation reactions which occur at a high temperature of all alloying elements of IN 625, the oxidation of $\mathrm{Nb}$ has the highest negative standard free energy, followed by $\mathrm{Cr}, \mathrm{Mo}$, and $\mathrm{Ni}$ [22].

The EDS analysis in the oxide scale formed during the first $24 \mathrm{~h}$ of exposure at $900{ }^{\circ} \mathrm{C}$ showed the presence of different amounts of other alloying elements such as $\mathrm{Ni}, \mathrm{Nb}, \mathrm{Mo}$, and $\mathrm{Fe}$, which contribute more to the formation of other phases than oxides such as $\delta$ phase, intermetallics, and carbides. Further, the $\mathrm{Cr}$ content in the oxide scale increases to the detriment of the other elements.

A different chemical composition evolution was registered in the case of higher-temperature oxidation. During the incipient phase, it was observed that specimens' surfaces were free of EDS quantitatively-measurable Mo and Fe contents, but reduced amounts of $\mathrm{Nb}$ and Ni were detected along with a higher content of $\mathrm{Cr}$. Moreover, the specimens oxidized at $1050^{\circ} \mathrm{C}$ exhibit a higher $\mathrm{Cr} / \Sigma \mathrm{AE}$ ratio in the middle and external oxide layers than those oxidized at $900{ }^{\circ} \mathrm{C}\left(0.97-0.98\right.$ at $1050{ }^{\circ} \mathrm{C}$ compared with $0.88-0.92$ at $900^{\circ} \mathrm{C}$ ).

The phase evolution and oxide scale crystallographic nature were determined using XRD. Based on XRD results, it was concluded that the isothermal oxidation at $900{ }^{\circ} \mathrm{C}$ and $1050{ }^{\circ} \mathrm{C}$ for small periods of time $(24 \mathrm{~h})$ lead to multiple phases development. Secondary phases such as $\delta$ phase $\left((\mathrm{Mo}, \mathrm{Nb}) \mathrm{Ni}_{3}\right)$, an Ni-rich intermetallic $\left(\mathrm{MoNi}_{4}\right)$, and complex carbides $\left((\mathrm{Cr}, \mathrm{Fe}, \mathrm{Mo} \text {, etc. })_{23} \mathrm{C}_{6}\right)$ were identified, with results consistent with the findings of other authors [29,30,40,42]. Longer exposure time at $900{ }^{\circ} \mathrm{C}$ resulted only in the dissolution of complex carbides, the $\gamma$-FCC and $\delta$ phases being still present along with $\mathrm{MoNi}_{4}$ intermetallic, while the exposure at the higher temperature for longer periods produced the dissolution of $\delta$ phase, $\mathrm{MoNi}_{4}$ intermetallic, and carbides.

Regarding the oxide scale's nature, the XRD analysis strengthened the finding of EDS results with respect to the development of $\mathrm{Cr}_{2} \mathrm{O}_{3}$ at both temperatures. Oxidation for $24 \mathrm{~h}$ at $900{ }^{\circ} \mathrm{C}$ led to the formation of $\mathrm{Cr}_{2} \mathrm{O}_{3}$ and a spinel $(\mathrm{Ni}, \mathrm{Fe}) \mathrm{Cr}_{2} \mathrm{O}_{4}$, while at a higher temperature, a more complex scale was registered. During the first $24 \mathrm{~h}$ of exposure at $1050{ }^{\circ} \mathrm{C}$, a higher ratio of $(\mathrm{Ni}, \mathrm{Fe}) \mathrm{Cr}_{2} \mathrm{O}_{4}$ spinel was developed, followed by $\mathrm{Cr}_{2} \mathrm{O}_{3}$ and also by another oxide characterized by a rutile-like structure $\left(\left(\left(\mathrm{Cr}^{+3}(\mathrm{Nb}, \mathrm{Ta})^{+5}\right)_{(1-\mathrm{x}) / 2},\left(\mathrm{Ti}^{+4}\right)_{\mathrm{x}}\right) \mathrm{O}^{-2}{ }_{2}\right)$. Prolonged exposure at $900{ }^{\circ} \mathrm{C}$ ensured the preservation of only the $\mathrm{Cr}_{2} \mathrm{O}_{3}$ scale, while at $1050{ }^{\circ} \mathrm{C}$ the same complex oxide scale was recorded. 
As it was stated before, in the last decade, an increased interest in additive manufacturing metallic materials was noticed, and the reliable integration of such materials in industrial applications might be soon a tangible fact. As for conventional materials, many studies were conducted regarding their behaviors in conditions that simulate the working environment, and therefore such studies still should be conducted for additive-manufactured materials. By their nature, AMed alloys are anisotropic materials from a microstructural and mechanical point of view as compared with the materials produced by conventional manufacturing technologies. Nevertheless, no significant differences were observed in the case of the oxidation behavior of additive-manufactured IN 625, as compared with the oxidation behavior of conventional manufactured material previously reported by other authors. The activation energy of the oxidative process, as well as the parabolic rate constants, are similar to the ones reported for conventional manufactured IN 625. The oxidation behavior of additive-manufactured IN 625 at high temperatures will be studied further, focusing on the oxidation impact on the material mechanical properties.

\section{Conclusions}

The high-temperature oxidation behavior of SLM-manufactured IN 625 was studied over $96 \mathrm{~h}$ at $900{ }^{\circ} \mathrm{C}$ and $1050{ }^{\circ} \mathrm{C}$ in air. Based on experimental results, it was concluded that the oxidative process is very fast during the first $24 \mathrm{~h}$ of exposure at both temperatures, slowing down after this holding period. Based on the mass gain analysis, it was found that the oxidation follows a parabolic law as a function of time during the first $24 \mathrm{~h}$ holding. For the specimens oxidized at $900{ }^{\circ} \mathrm{C}$, a steady mass gain was registered after $24 \mathrm{~h}$ (an almost linear dependence of the mass gain as a function of the exposure duration). At $1050{ }^{\circ} \mathrm{C}$, a rapid mass gain was recorded during the first holding cycle, followed by a constant mass gain until the 9 th cycle. After the 10 th exposure cycle at $1050{ }^{\circ} \mathrm{C}$, a weight decrease was registered, caused by the oxide scale spallation. The parabolic rate constants calculated for a total $96 \mathrm{~h}$ oxidation duration are $k_{p}=7.23 \times 10^{-13} \mathrm{~g}^{2} \cdot \mathrm{cm}^{-4} \cdot \mathrm{s}^{-1}$ at $900{ }^{\circ} \mathrm{C}$ and $k_{p}=1.67 \times 10^{-11} \mathrm{~g}^{2} \cdot \mathrm{cm}^{-4} \cdot \mathrm{s}^{-1}$ at $1050{ }^{\circ} \mathrm{C}$, leading to an oxidation activation energy $\mathrm{Q}=269.9 \mathrm{~kJ} \cdot \mathrm{mol}^{-1}$.

The high-temperature exposure for short periods led to the precipitation of $\delta$ phase, Ni-rich intermetallics, and complex carbides. Long holding periods at $900{ }^{\circ} \mathrm{C}$ ensured only the dissolution of carbides, while at higher temperature $\left(1050^{\circ} \mathrm{C}\right)$ the dissolution of all secondary phases was registered.

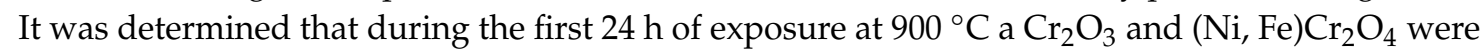
formed, while at $1050{ }^{\circ} \mathrm{C}$ a complex oxide scale consisting in $(\mathrm{Ni}, \mathrm{Fe}) \mathrm{Cr}_{2} \mathrm{O}_{4}, \mathrm{Cr}_{2} \mathrm{O}_{3}$ and rutile-type oxides $\left(\left(\left(\mathrm{Cr}^{+3}(\mathrm{Nb}, \mathrm{Ta})^{+5}\right)_{(1-\mathrm{x}) / 2}\left(\mathrm{Ti}^{+4}\right)_{\mathrm{x}}\right) \mathrm{O}^{-2}{ }_{2}\right)$ emerged. The same complex oxide was found out even after prolonged holding periods at $1050{ }^{\circ} \mathrm{C}$, but at $900{ }^{\circ} \mathrm{C}$ only the $\mathrm{Cr}_{2} \mathrm{O}_{3}$ scale was still present.

No significant differences were noticed in the case of oxidation behavior of additive-manufactured IN 625 as compared with the existing reported behavior of the conventional manufactured material.

Author Contributions: Conceptualization, M.R.C. and G.M.; methodology, M.R.C., G.M. and A.P.; investigation M.R.C., A.P., T.B., V.B.; formal analysis M.R.C. and G.M., data curation G.M., writing-original draft preparation, M.R.C. and G.M. All authors have read and agreed to the published version of the manuscript.

Funding: This research was carried out under the "Nucleu" Program, Grant no. 2N/2019, Project PN 19.05.03.01, funded by Romanian Research and Innovation Ministry, and the APC was funded by the Romanian Research and Innovation Ministry through Program 1-Development of the National Research System-Subprogram 1.2-Institutional Performance-Projects for Excellence Financing in RDI, Grant no. 3PFE/2018.

Conflicts of Interest: The authors declare no conflict of interest. 


\section{Appendix A}

Table A1. Description of the phases identified using XRD in the analyzed oxidized samples.

\begin{tabular}{|c|c|c|c|}
\hline $\begin{array}{l}\text { Empirical Formula } \\
\text { from PDF \# }\end{array}$ & Assumed Approximate Formula & $\begin{array}{c}\text { Symbol } \\
\text { Phase Name }\end{array}$ & Structure Type \\
\hline $\mathrm{Cr}_{0.08} \mathrm{Fe}_{0.65} \mathrm{Ni}_{0.27}-\mathrm{PDF}$ 04-020-3001 & (Ni, Cr, Fe, etc.) & $\begin{array}{c}\gamma \\
\gamma \text {-phase }\end{array}$ & $\begin{array}{l}\text { Type A1, } \\
\text { like Cu }\end{array}$ \\
\hline $\mathrm{Cr}_{1.776} \mathrm{Mo}_{0.112} \mathrm{O}_{3}-\mathrm{PDF}$ 01-070-4368 & $(\mathrm{Cr}, \mathrm{Fe})_{2-2 \mathrm{x}} \mathrm{Mo}_{\mathrm{x}} \mathrm{O}_{3}$ & $\begin{array}{c}\mathrm{C} \\
\text { ss } \mathrm{Cr}_{2} \mathrm{O}_{3}\end{array}$ & $\begin{array}{c}\text { Type D51, } \\
\text { like Corundum }\end{array}$ \\
\hline $\mathrm{NiCr}_{2} \mathrm{O}_{4}-\mathrm{PDF}$ 01-075-0198 & $\left(\mathrm{Ni}^{+2}, \mathrm{Fe}^{+2}\right)\left(\mathrm{Cr}^{+3}, \mathrm{Fe}^{+3}\right)_{2} \mathrm{O}_{4}$ & $S$ & $\begin{array}{l}\text { Type H11, } \\
\text { like Spinel }\end{array}$ \\
\hline CrNbO4-PDF 01-081-0909 & $\begin{array}{l}\left(\left(\mathrm{Cr}^{+3}(\mathrm{Nb}, \mathrm{Ta})^{+5}\right)_{(1-\mathrm{x}) / 2}\left(\mathrm{Ti}^{+4}\right)_{\mathrm{x}}\right) \mathrm{O}^{-2}{ }_{2} \\
\left(\left(\mathrm{Cr}^{+3}(\mathrm{Nb}, \mathrm{Ta})^{+5}\right)_{(1-\mathrm{x})}\left(\mathrm{Ti}^{+4}\right)_{2 \mathrm{x}}\right) \mathrm{O}^{-2}{ }_{4}\end{array}$ & $\begin{array}{c}R \\
\text { ss }(\mathrm{Cr}, \mathrm{Nb}, \mathrm{Ta}, \\
\mathrm{Ti}) \mathrm{O}_{2} \\
\end{array}$ & $\begin{array}{l}\text { Type C4, } \\
\text { like Rutile }\end{array}$ \\
\hline$\left(\mathrm{Mo}_{0.5} \mathrm{Nb}_{0.5}\right) \mathrm{Ni}_{3}-\mathrm{PDF}$ 04-003-9867 & $(\mathrm{Mo}, \mathrm{Nb}) \mathrm{Ni}_{3}$ & $\begin{array}{c}\delta \\
\delta \text {-phase }\end{array}$ & $\begin{array}{c}\text { Type D0a, } \\
\text { like } \beta-\mathrm{TiCu}_{3}\end{array}$ \\
\hline $\mathrm{MoNi}_{4}-\mathrm{PDF}$ 04-019-2633 & $\mathrm{MoNi}_{4}$ & $\bullet$ & $\begin{array}{l}\text { Type D1a, } \\
\text { like } \mathrm{MoNi}_{4}\end{array}$ \\
\hline $\mathrm{Cr}_{23} \mathrm{C}_{6}-\mathrm{PDF}$ 04-007-8810 & $(\mathrm{Cr}, \mathrm{Fe}, \mathrm{Mo}, \mathrm{etc} .)_{23} \mathrm{C}_{6}$ & $\begin{array}{l}\text { complex } \\
\text { carbid }\end{array}$ & $\begin{array}{l}\text { Type D84, } \\
\text { like } \mathrm{Cr}_{23} \mathrm{C}_{6}\end{array}$ \\
\hline
\end{tabular}

\section{References}

1. Reed, R.C. The Superalloys: Fundamentals and Applications; Cambridge University Press: New York, NY, USA, 2006.

2. Lund, C.H.; Wagner, H.J. Oxidation of Nickel-and Cobalt-Base Superalloys; DMIC Report 214; Battelle Memorial Institute: Columbus, OH, USA, 1965.

3. Eiselstein, H.L.; Tillack, D.J. The Invention and Definition of Alloy 625. In Superalloys 718, 625 and Various Derivatives; TMS: Pittsburgh, PA, USA, 1991; pp. 1-14.

4. DuPont, J.N.; Lippold, J.C.; Kiser, S.D. Welding Metallurgy and Weldability of Nickel-based Alloys; John Wiley \& Sons, Inc.: Hoboken, NJ, USA, 2019.

5. Donachie, M.J.; Donachie, S.J. Superalloys: A Technical Guide, 2nd ed.; ASM International: Cleveland, $\mathrm{OH}$, USA, 2002.

6. Park, S.J.; Seo, S.M.; Yoo, Y.S.; Jeong, H.W.; Jang, H.J. Statistical Study of the Effects of the Composition on the Oxidation Resistance of Ni-Based Superalloys. J. Nanomater. 2015, 1-11. [CrossRef]

7. Stott, F.H. Principles of Growth and Adhesion of Oxide Scales. In The role of Active Elements in the Oxidation Behaviour High Temperature Metals and Alloys; Lang, E., Ed.; Elsevier Science Publishers Ltd.: London, UK, 1989; pp. 3-22.

8. Birks, N.; Meier, G.H.; Pettit, F.S. Oxidation of alloys. In Introduction to the High Temperature Oxidation of Metals, 2nd ed.; Cambridge University Press: New York, NY, USA, 2006; pp. 101-162.

9. Sato, A.; Moverare, J.J.; Hasselqvist, M.; Reed, R.C. On the Oxidation Resistance of Nickel-Based Superalloys. Adv. Mater. Res. 2011, 278, 174-179.

10. Darolia, R. Development of strong, oxidation and corrosion resistant nickel-based superalloys: Critical review of challenges, progress and prospects. Int. Mat. Rev. 2019, 64, 355-380. [CrossRef]

11. Brenneman, J.; Wei, J.; Sun, Z.; Liu, L.; Zou, G.; Zhou, Y. Oxidation behavior of GTD111 Ni-based superalloy at $900{ }^{\circ} \mathrm{C}$ in air. Corros. Sci. 2015, 100, 267-274. [CrossRef]

12. Zhang, H.; Yang, Z.; Wu, Z.; Hong, X.; Li, Z.; Xu, Y.; Li, J.; Ni, G.; Xiao, X. Oxide-Scale Evolution on a New Ni-Fe-Based Superalloy at High Temperature. Oxid. Met. 2019, 92, 49-65. [CrossRef]

13. Chattopadhyay, B.; Wood, G.C. The transient oxidation of alloys. Oxid. Met. 1970, 2, 372-399. [CrossRef]

14. Kitaguchi, H. Microstructure-Property Relationship in Advanced Ni-Based Superalloys. In Metallurgy-Advances in Materials and Processes; Pardhi, Y., Ed.; IntechOpen: Rijeka, Croatia, 2012; pp. 19-42. 
15. Lai, H. High Temperature Oxidation and Corrosion of Ni-Based Superalloy for industrial Gas Turbines. Ph.D. Thesis, Chalmers University of Technology, Gothenburg, Sweden, 2014.

16. Pint, B.A.; Dryepondt, S.; Unocic, K.A. Oxidation of Superalloys in External Environments. In Proceedings of the 7th International Symposium on Superalloy 718 and Derivatives, Pittsburgh, PA, USA, 10-13 October 2010; Ott, E.A., Groh, J.R., Banik, A., Dempster, I., Gabb, T.P., Helmink, R., Liu, X., Michell, A., Sjoberg, G.P., Wusatowska-Sarnek, A., Eds.; TMS: Pittsburgh, PA, USA, 2010; pp. 861-875.

17. Berthod, P. Kinetics of High Temperature Oxidation and Chromia Volatilization for a Binary Ni-Cr Alloy. Oxid. Met. 2005, 64, 235-252. [CrossRef]

18. Huang, L.; Sun, X.F.; Guan, H.R.; Hu, Z.Q. Oxidation Behavior of a Single-Crystal Ni-base Superalloy in Air at 900,1000 and $1100{ }^{\circ} \mathrm{C}$. Oxid. Met. 2006, 65, 207-222. [CrossRef]

19. Li, M.H.; Sun, X.F.; Jin, T.; Guan, H.R.; Hu, Z.Q. Oxidation Behavior of a Single-Crystal Ni-base Superalloy in Air-II: At 1000, 1100, and $1150{ }^{\circ}$ C. Oxid. Met. 2003, 60, 195-210. [CrossRef]

20. Li, M.H.; Sun, X.F.; Li, J.G.; Zhang, Z.Y.; Jin, T.; Guan, H.R.; Hu, Z.Q. Oxidation Behavior of a Single-Crystal Ni-Base Superalloy in Air I: At 800 and $900{ }^{\circ} \mathrm{C}$. Oxid. Met. 2003, 59, 591-605. [CrossRef]

21. Young, D.J. The Nature of High Temperature Oxidation. In High Temperature Oxidation and Corrosion of Metals; Burstein, T., Ed.; Elsevier: Cambridge, UK, 2008; Volume 1, pp. 1-27.

22. Staszewska, K.; Scendo, M. Mechanism and Kinetics Oxidation of Inconel 617 and Inconel 625 Alloys. Tech. Issues 2016, 1, 82-89.

23. Vesel, A.; Drenik, A.; Elersic, K.; Mozetic, M.; Kovac, J.; Gyergyek, T.; Stockel, J.; Varju, J.; Panek, R.; Balat-Pichelin, M. Oxidation of Inconel 625 superalloy upon treatment with oxygen or hydrogen plasma at high temperature. Appl. Surf. Sci. 2014, 305, 674-682. [CrossRef]

24. Molins, R.; Andrieu, E. Analytical TEM study of the oxidation of nickel based superalloys. J. Phys. IV France 1993, 3, 469-475. [CrossRef]

25. Sand, T.; Geers, C.; Cao, Y.; Svensson, J.E.; Johansson, L.G. Effective Reduction of Chromium-oxy-hydroxide Evaporation from Ni-Base Alloy 690. Oxid. Met. 2019, 92, 259-279. [CrossRef]

26. Santecchia, E.; Spigarelli, S.; Cabibbo, M. Materials Reuse in Laser Power Bed Fusion: Side Effects on the Laser-Metal Powder Interaction. Metals 2020, 10, 341. [CrossRef]

27. Qin, H.; Xu, R.; Lan, P.; Wang, J.; Lu, W. Wear Performance of Metal Materials Fabricated by Powder Bed Fusion: A Literature Review. Metal 2020, 10, 304. [CrossRef]

28. Nagahari, T.; Nagoya, T.; Kakehi, K.; Sato, N.; Nakano, S. Microstructure and Creep Properties of Ni-Base Superalloy IN718 Built up by Selective Laser Melting in a Vacuum Environment. Metals 2020, 10, 362. [CrossRef]

29. Kang, Y.J.; Yang, S.; Kim, Y.K.; AlMangour, B.; Lee, K.A. Effect of post-treatment on the microstructure and high-temperature oxidation behaviour of additively manufactured Inconel 718 alloy. Corros. Sci. 2019, 158, 108082. [CrossRef]

30. Buscail, H.; Rolland, R.; Issartel, C.; Rabaste, F.; Riffard, F.; Aranda, L.; Vilasi, M. Effects of water vapour on the oxidation of a nickel-base 625 alloy between 900 and $1100{ }^{\circ}$ C. J. Mater. Sci. 2011, 46, 5903-5915. [CrossRef]

31. Chyrkin, A.; Huczkowsiki, P.; Shemet, V.; Singheiser, L.; Quadakkers, W.J. Sub-Scale Depletion and Enrichment Process During High Temperature Oxidation of the Nickel Base Alloy 625 in the Temperature Range $900-1000{ }^{\circ}$ C. Oxid. Met. 2011, 75, 143-166. [CrossRef]

32. N'dah, E.; Hierro, M.P.; Borrero, K.; Perez, F.J. Study of the Cyclic Oxidation Resistance of Superalloy IN 625: Lifetime Predicted by COSP-Modelling Program. Oxid. Met. 2007, 68, 9-21. [CrossRef]

33. Julliet, C.; Oudriss, A.; Balmain, J.; Feaugas, X.; Pedreza, F. Characterization and Oxidation resistance of additive manufactured and forged IN718 Ni-based superalloys. Corros. Sci. 2018, 142, 266-276. [CrossRef]

34. Colas, J.; Charpentier, L.; Balat-Pichelin, M. Oxidation in Air at $1400 \mathrm{~K}$ and Optical Properties of Inconel 625, FeCrAlloy and Kanthal Super ER. Oxid. Met. 2020, 93, 355-370. [CrossRef]

35. Whitney, E.; Simkovich, G.; Fink, J. High Temperature Oxidation of a Modified Alloy 625. In Superalloys 718, 625, 706 and Various Derivatives; Loria, E.A., Ed.; TMS: Pittsburg, PA, USA, 1997; pp. 695-704.

36. Kumar, L.; Venkataramani, R.; Sundararaman, M.; Mukhopadhyay, P.; Garg, S.P. Studies on the Oxidation Behavior of Inconel 625 Between 873 and 1523 K. Oxid. Met. 1996, 45, 221-244. [CrossRef]

37. Encinas-Orpesa, A.; Drew, G.L.; Hardy, M.C.; Leggett, A.J.; Nichollas, J.R.; Simms, N.J. Effects of Oxidation and Hot Corrosion in a Nickel Disc Alloy. In Superalloys 2018; Reed, R.C., Green, K.A., Caron, P., Gabb, T.P., Fahrmann, M.G., Huron, E.S., Woodard, S.A., Eds.; TMS: Pittsburg, PA, USA, 2008; pp. 609-618. 
38. Cruchley, S.; Evans, H.E.; Taylor, M.P.; Hardy, M.C.; Stekovic, S. Chromia layer growth on a Ni-based superalloy: Sub-parabolic kinetics and the role of titanium. J. Corr. Sci. 2013, 75, 58-66. [CrossRef]

39. Gorman, D.M.; Higginson, R.L.; Du, H.; McColvin, G.; Fry, A.T.; Thomson, R.C. Microstructural Analysis of IN617 and IN 625 Oxidised in the Presence of Steam for use in Ultra-Supercritical Power Plant. Oxid. Met. 2013, 79, 553-566. [CrossRef]

40. Mariano de Sousa Malafaia, A.; Brino de Oliveira, R.; Latu-Romain, L.; Wouters, Y.; Baldan, R. Isothermal oxidation of Inconel 625 superalloy at 800 and $1000{ }^{\circ} \mathrm{C}$ : Microstructure and oxide layer characterization. J. Mater. Char. 2020, 161, 110160. [CrossRef]

41. Chyrkin, A.; Huczkowsiki, P.; Shemet, V.; Singheiser, L.; Quadakkers, W.J. Predicting Subsurface Enrichment/Depletion Processes During High-Temperature Oxidation of Alloy 625 Thin Foils. Australas. Corros. Assoc. 2012, 2, 1556.

42. Garcia-Fresnillo, L.; Chyrkin, A.; Böhme, C.; Barnikel, J.; Schmitz, F.; Quadakkers, W.J. Oxidation behaviour and microstructural stability of alloy 625 during long-term exposure in steam. J. Mater. Sci. 2014, 49, 6127-6142. [CrossRef]

(C) 2020 by the authors. Licensee MDPI, Basel, Switzerland. This article is an open access article distributed under the terms and conditions of the Creative Commons Attribution (CC BY) license (http://creativecommons.org/licenses/by/4.0/). 